\title{
Public Inputs and Dynamic Producer Behavior: Endogenous Growth in U.S. Agriculture ${ }^{1}$ \\ Alejandro Onofri and Lilyan E. Fulginiti ${ }^{2}$
}

\begin{abstract}
This paper is an attempt to understand the impact of public R\&D and public infrastructure on the performance of the U.S. agricultural sector during the last part of the twentieth century. A neoclassical Solow growth model is not sufficient for this understanding given the sustained growth performance of the sector. We base our analysis on a well known endogenous growth model, the 'AK model' where nonconvexities are introduced through nonrival inputs. Based on these models and within the dynamic models that rationalize private and public decision making, we have identified three testable hypotheses regarding the aggregate agricultural production technology. They are: 1) increasing returns to scale over all inputs; 2) positive effect of additional units of public inputs on the long-run demand for private capital; and 3) negative impact of public inputs on cost. They are tested using two estimation procedures on two data sets for U.S. agriculture. One, covering the period 19481994, developed by USDA, the other, covering the period 1926-1990, from Thirtle et al. Maximum likelihood estimates do not conform to the regularity and behavioral properties of the model rendering them unusable for testing these hypotheses. Bayesian estimates, although not totally satisfactory, do not reject the hypotheses after prior imposition of some of the regularity conditions. This supports the notion of an important role for public inputs on the rapid and sustained growth of the sector. We calculate that, on average, one additional dollar spent on public $R \& D$ stock reduces private cost by $\$ 6.5$, implying a return on these public expenses of 190 percent.
\end{abstract}

\section{JEL Classification: D21, Q16}

Keywords: non-rival inputs, endogenous growth, 'AK' models, dynamics, returns to public inputs, U.S. agriculture.

\footnotetext{
${ }^{1}$ Paper prepared for presentation at the Department of Agricultural and Resource Economics, University of California, Davis, February 2006. A previous version was presented at the IX EWEPA, Brussels, June 2005. We thank Dick Perrin for comments on this manuscript.

${ }^{2}$ Centro de Investigacion y Docencia en Economia para el Desarrollo and Universidad Nacional de La Plata, Argentina, and Department of Agricultural Economics, University of Nebraska, respectively. Contact author: Lilyan E. Fulginiti, lfulginiti@unl.edu.
} 


\section{PUBLIC INPUTS AND DYNAMIC PRODUCER BEHAVIOR: Endogenous Growth in U.S. Agriculture}

\section{Introduction}

Neoclassical models of growth (Solow, Ramsey) have been widely criticized because they cannot explain productivity changes. According to these models, growth is exogenously given by an unexplained rate of technical change. As a response, endogenous growth theories prove that continuous growth is possible if there are non-rival inputs in production (i.e., inputs that can be used by many firms at the same time or by the same firm repeatedly without additional cost). In these models, two necessary conditions for endogenous growth are: increasing returns to scale over all inputs, and positive impacts of non-rival inputs on the returns to investment. The main contribution of this study is to introduce a dynamic model of productivity measurement that incorporates public goods (non-rival by definition) as external factors to the firms. It also rationalizes the provision of public inputs by a benevolent social planner that internalizes their effect. Estimable functions that allow testing the necessary conditions for endogenous growth are obtained.

Many other papers have focused on the effects of public goods on private production, and most of them have found positive impacts ${ }^{3}$. For example, Aschauer's (1989) pioneering work estimates a single production function for the U.S. economy including public infrastructure as a factor of production. Lynde and Richmond (1992) and Berndt and Hansson (1992) have also used duality theory to estimate the role of infrastructure in private production in the U.S. and Sweden, respectively. Nadiri and Mamuneas (1994) estimate the impacts of public capital and research and development (R\&D) on the cost structure of twelve U.S. manufacturing industries, and Morrison and Schwartz (1996) study the regional effects of public infrastructure on the U.S. manufacturing sector. Both of the latter papers adopt a dual approach and find, in general, positive effects of public inputs on manufacturing productivity. The last paper also finds increasing returns to scale over all inputs (including infrastructure), but it does not include R\&D.

For the agricultural sector, papers like Antle (1983) and Craig et al. (1997) find positive effects of public infrastructure and research on agricultural productivity but their approach is based on estimating a single production function. Binswanger et al. (1993) estimates the impacts of infrastructure and R\&D in India. They consider, in a static framework, that public infrastructure investments are regionally allocated toward areas that are more productive. Huffman et al. (2002) estimates the impact of R\&D and public infrastructure for five Midwestern states using a static cost function approach. They estimate a large and negative impact of these variables on cost. In contrast, the present study presents a dynamic model of growth used within the context of a simple endogenous growth model. This approach, based on duality theory, maintains private and public rationality and allows examination of the impacts of public inputs on producers' and government behavior.

The model is tested with data for the U.S. agricultural sector. United States agricultural productivity has increased at an annual average rate of two percent over the 19481994 period. Some authors have found that productivity growth has been the main factor

\footnotetext{
${ }^{3}$ Exceptions are Garcia-Mila and McGuire (1992) and Holtz-Eakin (1994). They find insignificant effects of public infrastructure on private production.
} 
contributing to economic growth of the agricultural sector (Ball et al., 1997). Additionally, the provision of public goods in the form of public research, extension, and infrastructure has been sizable in this country. In an atomistic environment, these public expenditures are traditionally justified because of their low degree of appropriability and high initial costs. We ask if permanent changes in government policies have generated permanent changes in growth rates of the sector.

Here, theoretically consistent dynamic firm-level demands for inputs that include the stocks of public infrastructure and R\&D are estimated for U.S. agriculture. The existence of economies of scale and the likely positive impact of public inputs on the steady state stocks of private capital are tested. From the assumption of rationality in government behavior, the optimal provision of public goods is examined. The relationship between the public objective of a benevolent social planner and that of the private firms allows derivation of an important condition that we test: that public inputs should reduce the private costs of production.

There are several other reasons to undertake this study that go beyond the understanding of the persistently high rate of growth of productivity in U.S. agriculture. First, the possibility of endogenous growth in the agricultural sector may imply spillovers to other sectors and, in particular, may have important effects on the growth of regional economies based on agricultural activities. Second, Ball et al. (1997) show the increasing use of materials and the decreasing use of labor in the U.S. agricultural sector. By determining the substitution or complementarity between public and private inputs, one may explain the findings by Ball et al. with respect to this evolution of quantities demanded of private factors. Third, we hope to add evidence to the academic debate over the virtues of endogenous growth theories over more traditional approaches to understand growth. It will also point towards a powerful role of public policies in this process. Finally, the estimation of shadow prices for public capital and R\&D stocks may provide an indicator to policy makers of the optimal provision of public investment.

This paper develops as follows. Section II presents a summary of the endogenous growth theory involving publicly provided goods and the related testable hypotheses. Section III introduces a dynamic model in which both the behavior of producers' and government are rationalized. The testable hypotheses are then revisited. Section IV introduces the empirical model and section V presents the results. Finally, conclusions are stated in section VI.

\section{Growth Theory and Testable Hypotheses}

In the neoclassical models of growth (Solow, Ramsey), the rate of growth of per capita output is a decreasing function of the per capita stock of private capital. Without technical change and with a well-behaved neoclassical production function, the level of per capita output converges to a steady state where the growth of per capita private capital eventually stops. This result, implied by the assumption of decreasing returns to capital, has been one of the major criticisms to these models.

As a response to these empirically unsustainable results, endogenous growth theory arose proposing different hypotheses. Some of these theories incorporate into the models the reasons for technical change to occur based on the presence of externalities that originate nonconvexities. 
Nonconvexities play an important role in new theories of growth. They are generally due to the presence of nonrival goods. Following Romer (1990), nonrivalry can be interpreted in two ways. First, nonrival factors of production are valuable "inputs that can be used simultaneously in more than one activity." Under this definition, public goods, like public infrastructure for instance, are nonrival inputs that can be used by many producers at the same time. Alternatively, one can define a nonrival input as that input that can be used repeatedly in the same activity. With this definition, a new chemical process, for example, is an input that can be used more than once in the production of a certain product. In this case, nonconvexities are intrinsically associated to this input: there is a high cost of producing the first unit, but the cost of producing subsequent units is zero. In any case, since the presence of nonrival inputs generates nonconvexities, the production function can be characterized by increasing returns to scale:

$$
\mathrm{F}(\lambda \mathrm{R}, \lambda \mathrm{N})>\mathrm{F}(\lambda \mathrm{R}, \mathrm{N})=\lambda \mathrm{F}(\mathrm{R}, \mathrm{N}), \text { with } \lambda>0
$$

where $\mathrm{R}$ and $\mathrm{N}$ stand for rival input and nonrival inputs, respectively. Thus, if rival and nonrival inputs are doubled $(\lambda=2)$, output is more than doubled.

One of the pioneer studies in the endogenous growth literature has been that by Romer (1986). In this paper, Romer specifies a production function $\mathrm{F}\left(\mathrm{k}_{\mathrm{i}}, \mathrm{K}, \mathbf{x}_{\mathrm{i}}\right)$, with $\mathrm{k}_{\mathrm{i}}$ and $\mathbf{x}_{\mathrm{i}}$ being firm-specific inputs ( $\mathbf{x}$ can be seen as a vector of inputs) and $\mathrm{K}$ an input external to the firm, like "the level of knowledge" defined as a function of the "firm-specific knowledge" $\left(\mathrm{K}=\mathrm{g}\left(\sum \mathrm{k}_{\mathrm{i}}\right)\right)$. If $\mathrm{F}$ is increasing in $\mathrm{K}$ and linearly homogeneous in $\mathrm{k}_{\mathrm{i}}$ and $\mathbf{x}_{\mathrm{i}}$, a perfectly competitive equilibrium is still possible, but the factor $\mathrm{k}_{\mathrm{i}}$ no longer exhibits diminishing returns. Consequently, permanent endogenous growth of output per capita is allowed.

Barro (1990) has developed a similar model where K can be interpreted as the stock of public capital (hereafter G). The intuition is that publicly provided capital (like roads, sewer capital, etc.) has a positive impact on private production affecting the productivity of the firmspecific inputs. Public capital is assumed a public input that can be used by additional producers without cost. Consequently, total stocks of public goods enter into the production function of each individual firm. In this context, two necessary conditions for the hypothesized endogenous growth are: existence of increasing returns to scale over all inputs, and existence of constant returns to scale over factors that can be accumulated. This second condition implies that private capital is continuously accumulated and there is an optimal ratio between private to public capital. A weaker requirement, alternative to this condition, would be a positive impact of $\mathrm{G}$ on the demand for capital. Although not ensuring continuous growth, the presence of this nonrival input would imply a positive government contribution to growth.

The conditions mentioned above (i.e., increasing returns to scale over all inputs and positive impact of public inputs on private capital accumulation) can be rationalized using the theory of the firm. The following section introduces a model in which firms respond to changes in public inputs provided by a benevolent social planner. Estimable functions that allow testing for the hypothesized endogenous growth conditions are then obtained in a model that maintains private and public rationality. 


\section{The Model}

A dynamic dual model of the firm is used to explain growth based on the existence of public inputs. As was hypothesized, public goods might have positive effects on firms' production. If the dual problem of the firms is considered, public inputs might reduce cost of production given the level of firms' output. In this manner, increases of public inputs would increase firms' productivity.

The model assumes that economic agents are intertemporal optimizers: firms minimize intertemporal costs of production and the government (social planner) maximizes intertemporal welfare. Instantaneous adjustment of inputs is not possible because of the existence of costs of adjustment.

In their optimizing behavior, firms take public inputs as given. Public inputs are considered fixed inputs of production in that they cannot be adjusted by the firm to obtain the minimum possible cost. However, the government, behaving as a social planner, observes the producers' surplus and provides public goods to maximize this surplus, subject to the cost of providing the public inputs.

The model adopted in this paper assumes that the government knows the payoff function of the firms. This assumption implies that the government knows how the firms react when public inputs are changed, i.e. the government behaves as a 'leader' and optimizes first. Then, firms take the level of public inputs as given and choose private inputs such that their costs of production are minimized.

The following figure shows the dynamics of behavior of this economy.

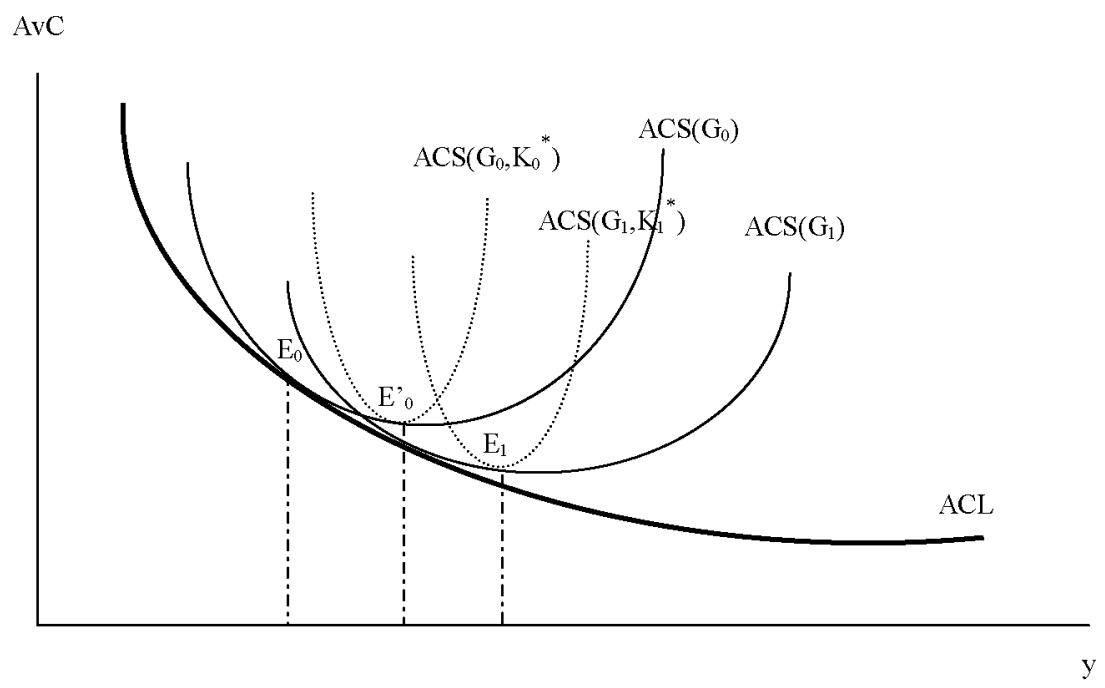

$\mathrm{G}$ represents the stock of the public input. $\mathrm{K}$ is the stock of private capital. Three average cost curves (faced by the firms) are shown in the graph. ACS $\left(G_{t}, K_{t}\right)$ represents a very short-run average cost curve when private inputs (capital in this case) and public inputs are fixed. $\operatorname{ACS}\left(\mathrm{G}_{\mathrm{t}}\right)$ is the short-run average cost curve when only public inputs are fixed. Finally, ACL is the long-run average cost curve when all inputs are adjusted. 
At each period $t$, the firms observe the public input stock $\mathrm{G}$ and choose the optimal path of investment (I) that allows them to reach the optimal steady state (SS) stock $\mathrm{K}^{*}$. Starting at $E_{0}$ and with a stock of public inputs $G_{0}$, firms choose an optimal path of $I$ that allows the firm to reach $\mathrm{K}_{0}{ }^{*}$ at the minimum cost. The firm moves from $\mathrm{E}_{0}$ to $\mathrm{E}_{0}{ }_{0}$. The path is adjusted the next period when the stock $\mathrm{G}_{1}$ implies a new $\mathrm{SS}$ stock $\mathrm{K}_{1}{ }^{*}$. The firm then moves to $E_{1}$. The two conditions for the hypothesized endogenous growth of the firms can then be seen in the graph:

I. Increasing returns to scale over the long-run average cost curve (ACL): negative slope of ACL.

II. Positive effects of $\mathrm{G}$ on the SS stocks of the private capital (i.e. the private input "that can be accumulated"): the SS stock of $\mathrm{K}$ increases from $\mathrm{K}_{0}{ }^{*}$ to $\mathrm{K}_{1}{ }^{*}$ when $\mathrm{G}$ grows from $\mathrm{G}_{0}$ to $\mathrm{G}_{1}$.

More formally, firms solve the following problem:

$$
\begin{array}{r}
\operatorname{Min}_{\mathrm{I}(\mathrm{t})>0} \int_{0}^{\infty} \mathrm{e}^{-\rho \mathrm{t}}\left[\mathrm{C}(\mathrm{y}, \mathrm{Z}, \mathrm{I} ; \mathrm{G})+\mathrm{p}^{\prime} \mathrm{Z}\right] \mathrm{dt} \\
\text { subject to } \dot{Z}=\mathrm{I}-\delta \mathrm{Z} \\
\mathrm{Z}(0)=\mathrm{Z}_{0} \\
\mathrm{Z}(\mathrm{t})>0 \quad \forall \mathrm{t}
\end{array}
$$

where $\mathrm{C}(\mathrm{y}, \mathrm{Z}, \mathrm{I} ; \mathrm{G})$ is the variable cost function; $\mathrm{y}$ is the only output; $\mathrm{Z}$ is the vector of stocks of quasi-fixed inputs; $p$ is the rental price vector corresponding to $Z$; $I$ is the vector of gross changes in quasi-fixed inputs; $\delta$ is the diagonal matrix containing the depreciation rates of $Z$; $G$ is the vector of public inputs; and $\rho>0$ is the firm's real rate of discount. It is assumed that there is one perfectly variable input whose price $(w)$ is normalized to one. ${ }^{4}$ Thus, the elements of $p$ are relative rental prices.

Define now $J(Z, y, p ; G)$ as the value function that solves problem (1). Assuming that $C(y, Z, I ; G)$ satisfies the set of regularity conditions (A.1) - (A.6) and $J(Z, y, p ; G)$ satisfies properties (B1) - (B5) (see Appendix 1), duality between $C(y, Z, I ; G)$ and $J(Z, y, p ; G)$ can be established.

Duality between $C(y, Z, I ; G)$ and $J(Z, y, p ; G):^{5}$ any $J(Z, y, p$; G.) satisfying conditions $(B)$ is the value function corresponding to $C(y, Z, I ; G)$ that satisfies conditions $(A)$ and is defined by

$$
\mathrm{C}(\mathrm{y}, \mathrm{Z}, \mathrm{I} ; \mathrm{G})=\underset{\mathrm{p}}{\operatorname{Max}}\left[\rho \mathrm{J}(\mathrm{Z}, \mathrm{y}, \mathrm{p} ; \mathrm{G})-\mathrm{p}^{\prime} Z-\mathrm{J}_{\mathrm{z}}{ }^{\prime}(\mathrm{Z}, \mathrm{y}, \mathrm{p} ; \mathrm{G})(\mathrm{I}-\delta \mathrm{Z})\right]
$$

or

$$
\rho J(Z, y, p ; G)=\underset{I}{\operatorname{Min}}\left[C(y, Z, I ; G)+p^{\prime} Z+J_{z}{ }^{\prime}(Z, y, p ; G)(I-\delta Z)\right]
$$

These two equations provide the relationship between the cost function $\mathrm{C}(\mathrm{y}, \mathrm{Z}, \mathrm{I} ; \mathrm{G})$ and the value function $\mathrm{J}(\mathrm{Z}, \mathrm{y}, \mathrm{p} ; \mathrm{G})$. They allow obtaining the properties of $\mathrm{C}(\mathrm{y}, \mathrm{Z}, \mathrm{I} ; \mathrm{G})$ in terms of the parameters of $\mathrm{J}(Z, y, p ; G)$ when firms minimize intertemporal costs. Thus, the derivative properties that characterize $\mathrm{C}(\mathrm{y}, \mathrm{Z}, \mathrm{I} ; \mathrm{G})$ can be recovered from the parameters of

\footnotetext{
${ }^{4}$ Given $w=1$, the variable cost function is $C(1, y, Z, I ; G)$. For simplification, $C(1, y, Z, I ; G)=C(y, Z, I ; G)$ is used.

${ }^{5}$ Epstein (1983).
} 
$\mathrm{J}(\mathrm{Z}, \mathrm{y}, \mathrm{p} ; \mathrm{G}){ }^{6}{ }^{6}$ Assuming rationality of the private decision making process provides guidance, in the form of a series of conditions, that need be satisfied by the empirics. In addition the two previously mentioned growth conditions can be tested through estimation of parameters of $\mathrm{J}(\mathrm{Z}, \mathrm{y}, \mathrm{p} ; \mathrm{G})$.

\section{Conditions for Endogenous Growth}

1) The impact of $G$ on

a) The cost function: this is provided by the fifth derivative property explained in Appendix 1. The following expression represents this effect:

$\mathrm{C}_{\mathrm{G}}(\mathrm{y}, \mathrm{Z}, \mathrm{I} ; \mathrm{G})=\rho_{\mathrm{G}}(\mathrm{Z}, \mathrm{y}, \mathrm{p} ; \mathrm{G})-\mathrm{J}_{\mathrm{ZG}}(\mathrm{Z}, \mathrm{y}, \mathrm{p} ; \mathrm{G}) \dot{Z}^{*}(\mathrm{Z}, \mathrm{y}, \mathrm{p} ; \mathrm{G})$

which is the shadow price of $\mathrm{G}$ when the firms are out of the SS. At the SS, the shadow price is

$\mathrm{C}_{\mathrm{G}}(\mathrm{y}, \mathrm{Z}, \mathrm{I} ; \mathrm{G})=\rho \mathrm{J}_{\mathrm{G}}(\mathrm{Z}, \mathrm{y}, \mathrm{p} ; \mathrm{G})$

If this expression is negative, the shadow price of $\mathrm{G}$ is positive, meaning that public inputs reduce cost of production.

b) The dynamic demand for private capital: it can be shown that the dynamic demand for the quasi-fixed inputs $Z$ can be expressed as

$$
\dot{Z}^{*}(Z, y, p ; G)=M(p, G)[Z-\bar{Z}(p, G)]
$$

where $\bar{Z}(p, G)$ is the SS stock of $Z$ and $M(p, G)$ is a stable adjustment matrix. This expression yields a flexible accelerator adjustment path for the stocks $Z$ and is the reason for these dynamic models to be called "multivariate flexible accelerator models" (Epstein, 1983). The form of $M(p, G)$ is determined by the functional form of $\mathrm{C}(\mathrm{y}, \mathrm{Z}, \mathrm{I})$; however, only under certain conditions, it can be successfully expressed as an explicit function of the parameters of $C(y, Z, I){ }^{7}$ The effect of $G$ on the dynamic demand for $Z$ can then be decomposed into the effect on the adjustment matrix and the effect on the SS stock of $Z$. The condition for endogenous growth would be for $G$ to increase the SS stock of private capital K (one of the quasi-fixed factors of the firms). The effect on the adjustment matrix an effect on the speed of adjustment toward the SS. It is still required for this adjustment to be stable.

2) Scale Effects: there must be increasing returns to scale over all factors of production (public and private factors). Increasing returns to scale can be evaluated by considering the elasticity of cost with respect to output $\left(\varepsilon_{\mathrm{CY}}\right)$. It is well known in the production economics literature that the elasticity of cost with respect to output is the dual expression of the elasticity of scale $\left(\eta_{\mathrm{y}}\right): \varepsilon_{\mathrm{cy}}=1 / \eta_{\mathrm{y}}{ }^{8}$ When the elasticity of cost with respect to output is less than one, firms exhibit economies of scale. However, in the presence of factors external to the firm, some adjustments should be made in order to obtain $\varepsilon_{\text {cy. }}$ Morrison and Schwartz (1996) show how to adjust the elasticity of cost with respect to output when

\footnotetext{
${ }^{6}$ See Appendix 1 for the derivative properties.

${ }^{7}$ See Epstein (1983) for details.

${ }^{8}$ See Chambers (1988) for details.
} 
there are quasi-fixed inputs in a static cost minimization framework. ${ }^{9}$ This approach is used here for the case of intertemporal optimization. ${ }^{10}$

Define the shadow price of the public input $P G=P G(Z, y, p ; G)$. This shadow price can be interpreted as an "inverse demand" for the public input. Solving for G, given PG, gives the direct shadow demand for $G$ that can be substituted into (4) to get

$$
\begin{aligned}
\mathrm{C}\left(\mathrm{y}, \mathrm{Z}, \mathrm{I} ; \mathrm{G}\left(\overline{\mathrm{P}}_{\mathrm{G}}, \mathrm{Z}, \mathrm{y}, \mathrm{p}\right)\right) & =\underset{\mathrm{p}}{\operatorname{Max}}\left[\rho \mathrm{J}\left(\mathrm{Z}, \mathrm{y}, \mathrm{p} ; \mathrm{G}\left(\overline{\mathrm{P}}_{\mathrm{G}}, \mathrm{Z}, \mathrm{y}, \mathrm{p}\right)\right)-\mathrm{p}^{\prime} \mathrm{Z}-\right. \\
& \left.-\mathrm{J}_{\mathrm{z}}^{\prime}\left(\mathrm{Z}, \mathrm{y}, \mathrm{p} ; \mathrm{G}\left(\overline{\mathbf{P}}_{\mathrm{G}}, \mathrm{Z}, \mathrm{y}, \mathrm{p}\right)\right)(\mathrm{I}-\delta \mathrm{Z})\right]
\end{aligned}
$$

Taking the derivative with respect to $y$, we obtain the adjusted effect of output on cost when the 'shadow demand' for $G$ also changes with firms' output:

$$
\frac{\partial \mathrm{C}^{\mathrm{A}}}{\partial \mathrm{y}}=\rho \mathrm{J}_{\mathrm{y}}-\mathrm{J}_{\mathrm{zy}}^{\prime} \dot{\mathrm{Z}}^{*}+\left(\rho \mathrm{J}_{\mathrm{G}}^{\prime}-\dot{\mathrm{Z}}^{*^{\prime}} \mathrm{J}_{\mathrm{zG}}\right) \mathrm{G}_{\mathrm{y}}\left(\overline{\mathbf{P}}_{\mathrm{G}}, \mathrm{Z}, \mathrm{y}, \mathrm{p}\right)
$$

At the SS, this expression becomes

$$
\begin{aligned}
\frac{\partial C^{A}}{\partial y} & =\rho J_{y}+\rho J_{G}^{\prime} G_{y}\left(\bar{P}_{G}, Z, y, p\right) \\
& =C_{y}+C_{G}^{\prime} G_{y}\left(\bar{P}_{G}, Z, y, p\right)
\end{aligned}
$$

Completing elasticities gives the following equation

$$
\varepsilon_{\mathrm{CY}}^{\mathrm{A}}=\varepsilon_{\mathrm{CY}}+\sum_{\mathrm{G}} \varepsilon_{\mathrm{CG}} \varepsilon_{\mathrm{GY}}
$$

which is the elasticity of cost with respect to output adjusted for the presence of public inputs. Note that $\varepsilon_{C G}$ is the elasticity of cost with respect to external factors, and $\varepsilon_{\mathrm{GY}}$ is the elasticity of "demand for external factors" with respect to output. This demand elasticity should be interpreted as a long-run one representing the change in external factors necessary to maintain the firm on the envelope long-run average cost curve after a change in output. Therefore, if $\varepsilon_{C Y}^{\mathrm{A}}$ is less than one, then there are increasing returns to scale over all inputs.

\section{Government Behavior}

As already mentioned, the government behaves as a benevolent social planner. It provides public inputs to maximize welfare (producers' and consumers' surpluses less the cost of providing public inputs). A small open economy is assumed, so the output price is given.

\footnotetext{
${ }^{9}$ The approach is based on Le Chatelier principle. Taking the derivative with respect to $\mathrm{Y}$ on both sides of the identity $\mathrm{C}^{\mathrm{A}}(\mathbf{P}, \mathbf{P g}, \mathrm{Y}) \equiv \mathrm{C}(\mathbf{P}, \mathbf{G}(\mathbf{P}, \mathbf{P g}, \mathrm{Y}), \mathrm{Y})$ gives

Finally, completing elasticities gives

$$
\frac{\partial \mathrm{C}^{\mathrm{A}}}{\partial \mathrm{Y}}=\frac{\partial \mathrm{C}}{\partial \mathrm{Y}}+\sum_{\mathrm{G}} \frac{\partial \mathrm{C}}{\partial \mathrm{G}} \frac{\partial \mathrm{G}}{\partial \mathrm{Y}}
$$

$$
\varepsilon_{C Y}^{A}=\varepsilon_{C Y}+\sum_{G} \varepsilon_{C G} \varepsilon_{G Y}
$$

${ }^{10}$ Stefanou (1989) extends the concept of scale elasticity to a dynamic framework when the firm is not necessarily in steady state. He does not include external factors.
} 
Assuming that public inputs do not affect utility of consumers, the problem of the government is reduced to the maximization of producers' surplus. Then, in a dynamic model, the government solves the following problem

$$
\begin{gathered}
\underset{I_{g}>0}{\operatorname{Min}} \int_{0}^{\infty} e^{-\theta t}\left[J(y, Z, p ; G)+r^{\prime} G+A C\left(I_{g}\right)\right] d t \\
\text { subject to } \dot{G}=I_{g}-\delta_{g} G \\
G(0)=G_{0} \\
G(t)>0 \quad \forall t
\end{gathered}
$$

where $J(y, Z, p ; G)$ is the value function of the firms that comes from their intertemporal cost minimization problem; $I_{g}$ is the investment in public inputs which stocks are given by vector $\mathrm{G}$; $\mathrm{AC}\left(\mathrm{I}_{\mathrm{g}}\right)$ is the government's adjustment cost of $\mathrm{G}$; $\delta_{\mathrm{g}}$ is the diagonal matrix containing the depreciation rates of $\mathrm{G}$; $r$ is the rental price of $\mathrm{G}$; and $\theta$ is the government's rate of discount. The existence of adjustment costs is justified by the multiple activities the government does with given resources. Increasing $I_{g}$ means that the government must reallocate funds and resources used in the provision of some other public goods, like goods that provide utility to consumers or are inputs for producers in other sectors. This reallocation of resources implies that some resources are wasted in the process. This loss can then be modeled as an adjustment cost. $^{11}$

Define $\mathrm{J}^{\mathrm{g}}(\mathrm{p}, \mathrm{Z}, \mathrm{y} ; \mathrm{r}, \mathrm{G})$ as the government's value function that solves (8). Assuming that $J(Z, y, p ; G)+A C\left(I_{g}\right)$ satisfies conditions $(C .1)-(C .6)$ and $J^{g}(p, Z, y ; r, G)$ satisfies conditions (D.1) - (D.5) (see Appendix 2), duality between $J(Z, y, p ; G)+A C(I g)$ and $J^{g}(p, Z$, $y ; r, G)$ can be established.

Duality between $J(Z, y, p ; G)+A C\left(I_{g}\right)$ and $J^{g}(p, Z, y ; r, G)$ : any $J^{g}(p, Z, y ; r, G)$ satisfying conditions $(D)$ is the value function corresponding to $J(Z, y, p ; G)+A C\left(I_{g}\right)$ that satisfies conditions $(C)$ and is defined by

$$
J(Z, y, p ; G)+A C\left(I_{g}\right)=\operatorname{Max}_{r}\left[J^{g}(Z, y, p, r, G)-r^{\prime} G-J_{G}^{g}{ }^{\prime}(Z, y, p, r, G)\left(I_{g}-\delta_{g} G\right)\right]
$$

or

$$
{ }_{\theta} \mathbf{J}^{\mathrm{g}}(\mathrm{Z}, \mathrm{y}, \mathrm{p}, \mathrm{r}, \mathrm{G})=\underset{\mathrm{I}_{\mathrm{g}}}{\operatorname{Min}}\left[\mathrm{J}(\mathrm{Z}, \mathrm{y}, \mathrm{p} ; \mathrm{G})+\mathrm{r}^{\prime} \mathrm{G}+\mathrm{AC}\left(\mathrm{I}_{\mathrm{g}}\right)+\mathrm{J}_{\mathrm{G}}^{\mathrm{g}}{ }^{\prime}(\mathrm{Z}, \mathrm{y}, \mathrm{p}, \mathrm{r}, \mathrm{G})\left(\mathrm{I}_{\mathrm{g}}-\delta_{\mathrm{g}} \mathrm{G}\right)\right]
$$

These two expressions provide the relationship between $J(Z, y, p ; G)$, the value function of the firms, and $\mathrm{J}^{\mathrm{g}}(\mathrm{p}, \mathrm{Z}, \mathrm{y} ; \mathrm{r}, \mathrm{G})$, the value function of the government. They allow expressing the parameters of $J(Z, y, p ; G)$ in terms of the parameters of $J^{g}(p, Z, y ; r, G)$ and vice versa, when the government maximizes intertemporal welfare by minimizing producers' cost. Thus, the derivative properties that characterize $\mathrm{J}(\mathrm{Z}, \mathrm{y}, \mathrm{p} ; \mathrm{G})$ can be recovered from the parameters of $\mathrm{J}^{\mathrm{g}}(\mathrm{p}, \mathrm{Z}, \mathrm{y} ; \mathrm{r}, \mathrm{G}){ }^{12}$ It is one of these properties (D2 (ii)) that we use as a basis to expect and maintain the negative impact of public inputs on costs.

\footnotetext{
${ }^{11}$ Note that assuming the objective functions of consumers and producers are separable with respect to the objective function of problem (8), the government can decide the optimal provision of different public goods separately.

${ }^{12}$ See Appendix 2 for these derivative properties.
} 


\section{Empirical Implementation}

This section presents the empirical implementation of the model introduced above. Ideally, having data on $r$, the optimal path of $I_{g}$ could be estimated. Nevertheless, the contribution of public capital and public R\&D to U.S. agricultural growth and the conditions for the hypothesized endogenous growth can still be tested through estimation of the firms' demands for private inputs. Adopting a flexible functional form for the value function of the firms, all parameters of interest can be recovered from the estimation of the dynamic demands for private quasi-fixed inputs and the demand for the variable input.

The model presented above is tested using two data sets. ${ }^{13}$ The first data set covers the period 1948 - 1994 and in large part consists of the one developed by USDA based on the recommendations for consistent measurement and aggregation of the AAEA task force on statistics. Variables needed for estimation include quantity indexes of capital (K), labor (L), materials (M), and output (Y); implicit prices of the three inputs; and stocks of public inputs (public capital $(\mathrm{G})$ and $\mathrm{R} \& \mathrm{D}(\mathrm{R})) .{ }^{14} \mathrm{~K}$ is an aggregate measure of capital and land. Capital and labor are assumed quasi-fixed inputs, while materials are the only variable input. ${ }^{15}$ Output is an index of all crops and livestock products. Public capital stocks are values of federal, state, and local structures. Public R\&D stocks are constructed from R\&D spending using Chavas and Cox's method (1992). ${ }^{16}$ We will refer to this as Ball's data set.

The second data set, from Thirtle et al., covers the period 1926-1990 and is provided to the authors with the purpose of comparative examination ${ }^{17}$ with results to be presented at the IX European Efficiency and Productivity Analysis Workshop to meet in Brussels in June $2005{ }^{18}$ The same aggregate variables are included. Output is an aggregate of all crops and livestock products. $\mathrm{K}$ is an aggregate of capital and land. Public R\&D stocks are constructed from the R\&D spending provided by Thirtle et al. using the same method as in the previous data set. As this data set does not have an aggregate for materials, the fertilizer index is used along with the expenditures on materials for 1967 from Ball's to obtain the variable input series. Public infrastructure has been added to this data set and it is the same variable, extended, as described above. We will refer to this as Thirtle's data set.

\footnotetext{
${ }^{13}$ Table with data sets and graphs for each variable are found in Appendix 4.

${ }^{14}$ See Ball et al. (1997) for details on all agricultural data. Public capital stocks are from Survey of Current Business and include buildings, highways, streets, sewer structures etc. Military structures are excluded. Public R\&D spending is from Alston and Pardey (1996).

${ }^{15}$ The adoption of materials as a variable factor in agricultural production is consistent with the findings of previous studies, for example, Vasavada and Chambers (1986), Luh and Stefanou (1991, 1993).

${ }^{16}$ With this method, the stock for a given year is constructed as a weighted sum of the last thirty years of expenditures, in which the weights follow an inverted 'V' pattern. Huffman and Evenson's (1989) methodology, which consists of a trapezoidal pattern of thirty-five years of expenditures, was also tried. Results show no significant differences.

${ }^{17}$ This data set was also offered for modeling purposesto Professor Quirino Paris and Professor Rolf Färe.

${ }^{18}$ See Thirtle et al (2002) for details on the data set. Public capital stocks have been added to this data set and are the same as in Ball's data set. Quantities were obtained by multiplying the indexes by the expenditures for 1967 obtained from Ball's data set. Prices are implicit. The materials variable was obtained by multiplying the expenditures from Ball for 1967 by the fertilizer index from Thirtle. Dr. Stefanou provided a data series that includes 1910-1990 but due to lack of information on infrastrucuture before 1925 plus the need to construct a stock of R\&D capital reduced the length of the data set we worked with.
} 
Consider the following normalized quadratic value function: ${ }^{19}$

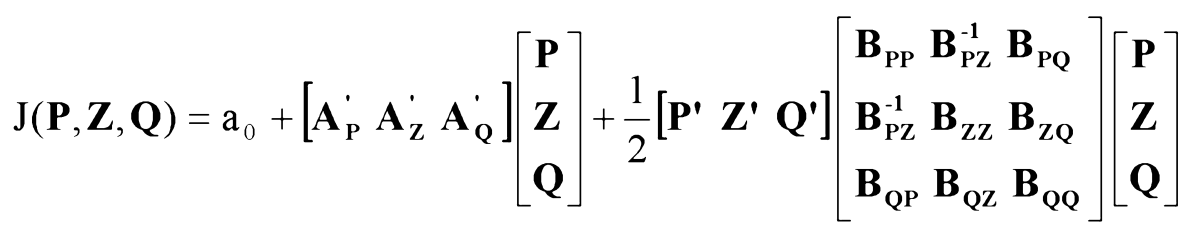

This is a second order Taylor series expansion of $\mathbf{J}$ in $(\mathbf{P}, \mathbf{Z}, \mathbf{Q})$, where $\mathbf{Z}$ is the vector of quasifixed factors, $\mathbf{P}$ is the corresponding vector of normalized rental prices, and $\mathbf{Q}$ is the vector of output and public inputs; $\mathbf{A}_{\mathrm{i}}$ is a $1 \times 7$ vector of first order parameters and $\mathbf{B}_{\mathrm{ij}}$ is a $7 \times 7$ matrix of parameters; $a_{0}$ is a scalar parameter. Then, the vectors $\mathbf{P}^{\prime}, \mathbf{Z}^{\prime}$, and $\mathbf{Q}^{\prime}$ are equal to

$$
\mathbf{P}^{\prime}=\left[\begin{array}{ll}
\mathrm{P}_{\mathrm{K}} & \mathrm{P}_{\mathrm{L}}
\end{array}\right] ; \quad \mathbf{Z}^{\prime}=\left[\begin{array}{ll}
\mathrm{K} & \mathrm{L}
\end{array}\right] ; \quad \mathbf{Q}^{\prime}=\left[\begin{array}{lll}
\mathrm{G} & \mathrm{R} & \mathrm{Y}
\end{array}\right] ;
$$

where $\mathrm{P}_{\mathrm{K}}$ and $\mathrm{P}_{\mathrm{L}}$ are the prices of capital and labor, respectively, normalized by the price of materials.

The dynamic demands for quasi-fixed inputs are then ${ }^{20,21}$

$$
\dot{\mathbf{Z}}^{*}(\mathbf{P}, \mathbf{Z}, \mathbf{Q})=\mathrm{J}_{\mathrm{pz}}^{-1}(\mathbf{P}, \mathbf{Z}, \mathbf{Q})\left[\rho \mathrm{J}_{\mathrm{p}}(\mathbf{P}, \mathbf{Z}, \mathbf{Q})-\mathbf{Z}\right]
$$

and the demand for the variable input $\left(\mathrm{X}^{*}\right)$ is calculated from

$$
X^{*}(P, Z, Q)=\rho\left[J(P, Z, Q)-J_{p}^{\prime}(P, Z, Q) P\right]-\left[J_{Z}^{\prime}(P, Z, Q)-p^{\prime} J_{P Z}\right] \dot{Z}^{*}
$$

In terms of the postulated value function, (12a) and (13a) become

$$
\begin{aligned}
\dot{\mathbf{Z}}^{*} & =\rho \mathbf{H}+\left(\rho \mathbf{u}-\mathbf{B}_{\mathrm{PZ}}\right) \mathbf{Z}+\rho \mathbf{B}_{\mathrm{PZ}} \mathbf{B}_{\mathrm{PP}} \mathbf{P}+\rho \mathbf{N} \mathbf{Q} \\
\mathbf{X}^{*} & =\rho\left[\mathbf{a}_{0}-\frac{\mathbf{1}}{\mathbf{2}} \mathbf{P}^{\prime} \mathbf{B}_{\mathrm{PP}} \mathbf{P}+\mathbf{A}_{\mathbf{Z}}^{\prime} \mathbf{Z}+\mathbf{A}_{\mathbf{Q}}^{\prime} \mathbf{Q}+\frac{\mathbf{1}}{\mathbf{2}} \mathbf{Z}^{\prime} \mathbf{B}_{\mathrm{ZZ}} \mathbf{Z}+\mathbf{Z}^{\prime} \mathbf{B}_{\mathrm{ZQ}} \mathbf{Q}+\right. \\
& \left.+\frac{\mathbf{1}}{\mathbf{2}} \mathbf{Q}^{\prime} \mathbf{B}_{\mathbf{Q Q}} \mathbf{Q}\right]-\left[\mathbf{A}_{\mathbf{Z}}^{\prime}+\mathbf{Z}^{\prime} \mathbf{B}_{\mathrm{ZZ}}+\mathbf{Q}^{\prime} \mathbf{B}_{\mathrm{ZQ}}^{\prime}\right] \dot{\mathbf{Z}}^{*}
\end{aligned}
$$

\footnotetext{
${ }^{19}$ Other studies that have used second-order expansions to approximate the value function in the agricultural sector include Vasavada and Chambers $(1982,1986)$, Vasavada and Ball, Howard and Shumway $(1988,1989)$, Taylor and Monson, Luh and Stefanou (1991, 1993, 1996), Fousekis and Stefanou, Lansink and Stefanou. ${ }^{20}$ To clarify notation, subscripts in the value function $\mathrm{J}$ denote gradient vectors. B and A are matrices of parameters.

${ }^{21}$ See Appendix 1 for derivation.
} 
where $\mathbf{H}=\mathbf{B}_{\mathrm{PZ}} \mathbf{A}_{\mathrm{P}}, \mathbf{N}=\mathbf{B}_{\mathrm{PZ}} \mathbf{B}_{\mathrm{PQ}}$, and $\mathbf{u}$ is a $2 \times 2$ identity matrix. Note that equations (12b) constitute the flexible accelerator with constant adjustment coefficients and can be rewritten as in Equation (4)

$$
\dot{\mathbf{Z}}^{*}(\mathbf{Z}, \mathbf{P}, \mathbf{Q})=\mathbf{M}[\mathbf{Z}-\overline{\mathbf{Z}}(\mathbf{P}, \mathbf{Q})]
$$

where

$$
\begin{aligned}
& \mathbf{M}=\left(\rho \mathbf{u}-\mathbf{B}_{\mathrm{PZ}}\right) \\
& \overline{\mathbf{Z}}=-\left(\rho \mathbf{u}-\mathbf{B}_{\mathrm{PZ}}\right)^{-1} \rho\left[\mathbf{H}+\mathbf{B}_{\mathrm{PZ}} \mathbf{B}_{\mathrm{PP}} \mathbf{P}+\mathbf{N Q}\right]
\end{aligned}
$$

$\overline{\mathbf{Z}}$ being the steady state values of private quasi-fixed inputs.

The model until now has been described in terms of continuous time. For estimation purposes, however, a discrete approximation to $\dot{\mathbf{Z}}$ must be used. $\mathbf{Z}_{-1}$ being the lag of $\mathbf{Z},(12 b)$ can be expressed as

$$
\mathbf{Z}=\rho \mathbf{H}+\left(\mathbf{u}+\rho \mathbf{u}-\mathbf{B}_{\mathbf{P Z}}\right) \mathbf{Z}_{-1}+\rho \mathbf{B}_{\mathrm{PZ}} \mathbf{B}_{\mathbf{P P}} \mathbf{P}+\rho \mathbf{N Q}
$$

Joint estimation of (12c) and (13b) gives all the parameters needed for testing the effects of public inputs on firms' costs, steady state stocks of capital, and scale. ${ }^{22.23}$

\section{Results}

With three private inputs, estimation of the system (12c)-(13b) implies joint estimation of three equations: two dynamic demands (for labor and capital) and the demand for the variable input. Additionally, the theoretical model implies that public inputs are simultaneously determined by $\mathbf{P}, \mathbf{Z}$ and $\mathrm{Y}$. Therefore, instrumental variables for the public inputs must be used. Accordingly, predicted values of $\mathrm{G}$ and $\mathrm{R}$ were then adopted for estimation of (12c)-(13b) by iterative nonlinear seemingly unrelated regressions (nonlinear

\footnotetext{
${ }^{22}$ This estimation assumes that farmers expect the current input prices to prevail in the future. In this way, optimization plans are revised each period when new information is obtained (i.e., when farmers observe the new prices).

${ }^{23}$ Note that the theory presented here is a theory of the firm. Nevertheless, the data used for estimation is highly aggregated. Consistent linear aggregation would require

$$
J(P, Z, Y, G, R)=\sum_{i} J\left(P, Z_{i}, Y_{i}, G, R\right)
$$$$
Z=\sum_{i} Z_{i} \text {, and } Y=\sum_{i} Y_{i}
$$

where the sum is across firms. The linear aggregation is over private quasi-fixed stocks and output because they are different across firms. For public inputs, however, this is not required because they are non-rival by definition: the same input (as long as they are not local public goods) can be used by many producers at the same time. Hence, for the quadratic value function presented above, consistent aggregation across firms requires linearity in $Z$ and $Y$, i.e., $J_{Z Z}=B_{Z Z}=0, J_{Z Y}=B_{Z Y}=0$, and $J_{Y Y}=b_{y y}=0$, where $B_{Z Y}$ is a partition matrix of $B_{Z Q}=\left[B_{Z G} B_{Z R} B_{Z Y}\right]$, and $b_{y y}$ is one element of $B_{Q Q}$. For the estimation presented below aggregation conditions were not imposed. When those conditions are imposed, there is no qualitative change in the results.
} 
ITSUR $)^{24}$ first and then by a Bayesian procedure. These procedures are used in both data sets, Ball's covering the 1948-1994 period and Thirtle's covering the 1926-1990 period. $^{25}$

As a reminder, the three hypotheses to be tested are:

1) The shadow price of public inputs is positive, meaning that public inputs reduce cost of production;

2) public inputs increase the steady state stock of private capital K; and

3 ) there must be increasing returns to scale over all factors of production (public and private factors).

\section{a. ITSUR Estimates.}

Table 1A presents the parameter estimates for Ball's data set. Estimated shadow prices of public infrastructure and public R\&D by decade are presented in Table $2 \mathrm{~A}$. A positive shadow price implies that the corresponding public input reduces agricultural costs of production. While positive shadow prices of public research were obtained for the whole sample period, shadow prices of infrastructure were all negative. Table 4A shows long-run impacts of the public inputs on the private inputs. While $R \& D$ increases the stock of private capital, infrastructure decreases it. In table $5 \mathrm{~A}$ we see that the third hypotheses is not confirmed either as our estimates indicate decreasing returns to scale in all inputs.

Table 1C presents the parameter estimates of the ITSUR estimation using Thirtle's data set. ${ }^{26}$ Estimated shadow prices of public infrastructure and public R\&D by decade are presented in Table 2C. Positive shadow prices of public research were obtained for all periods but the 1951-1960 period; in contrast, shadow prices of infrastructure were all negative. Estimates of long-run impacts of R\&D and infrastructure on private capital are seen on Table 4C. The elasticity of demand of private capital with respect to R\&D indicates that in steady state, an additional unit of $R \& D$ results in an increase in demand of private capital while the opposite is true for infrastructure. Table $5 \mathrm{C}$ shows the estimated returns to scale for this data set. It indicates increasing returns to scale during the whole period giving support to the third hypotheses of our model. Table 6 summarizes these results.

The necessary conditions presented in Appendix 1 and other regularity conditions of the economic theory can be checked using the parameter estimates, some are checked globally and others need to be to be checked locally at each data point. A summary of these checks is found in Table 8 . These maximum likelihood estimates violate some of the theoretical conditions.

\section{b. Bayesian Estimates.}

In order to obtain reliable estimates consistent with the economic theory of the firm, new estimations imposing a set of required conditions were performed. Some restrictions

\footnotetext{
${ }^{24}$ Instruments include total U.S. population, number of non-farm workers, interest rate of federal bonds, and total non-agricultural exports.

${ }^{25}$ SAS code is found in Appendix 6.

${ }^{26}$ To make the results comparable to those from Ball's data set, implicit price indexes were constructed using Ball's 1967 expenditures. Quantity indexes were normalized by setting the 1967 value equal to one (Appendix 4).
} 
imply the local imposition of inequality constraints, that is, the restrictions must be imposed at each data point. ${ }^{27}$ One way of doing this is using Bayesian estimation to introduce the desired conditions as prior beliefs.

Bayesian estimation entails calculation of the joint posterior distribution of the parameters. Analytical calculation of that distribution is, however, not possible, and sampling algorithms are generally used to simulate that joint posterior distribution. Different algorithms have been developed. This study follows the Metro-Hastings ( $\mathrm{MH})$ algorithm, a Markov Chain Monte Carlo (MCMC) simulation method that has already been used by Griffiths et al. (1999), O'Donnell et al. (1999) and O'Donnell (2002) in previous empirical economic studies.

As other sampling algorithms, the MH simulation method consists of generating draws of the parameters of interest from their conditional distribution. Because some restrictions need to be imposed in this case, the algorithm contains an accept-reject step in which new draws are included in the sample if those conditions are satisfied. In this way, the estimation is constrained to the parameter space that is consistent with economic theory. Additionally, iterations followed the process in which each random draw was conditioned on the last draw. After a certain number of iterations, that process converges to a random sample from the joint posterior distribution. The $\mathrm{MH}$ parameter estimates are then the mean of that random sample. $^{28}$

Estimated parameters are presented in Table 1B. Table 2B presents the shadow prices of public infrastructure and research by decade and their respective standard deviations. The shadows are positive for all decades and most of them are significantly different from zero. This is interpreted as a positive contribution of public inputs to growth of the US agricultural sector, supporting the first hypothesis.

Tables $3 \mathrm{~B}$ to $5 \mathrm{~B}$ show the short- and long-run elasticities of demand and the elasticities of cost with respect to output. Estimates of the long-run elasticities of demand indicate that, while infrastructure has had positive impacts on private capital accumulation, public research has substituted for private capital. Finally, elasticities of cost with respect to output, even after adjusting for the presence of public inputs, are larger than one, meaning that the U.S. agricultural sector has exhibited decreasing returns to scale, contrary to the postulated endogenous growth condition.

Bayesian estimates of the parameters using Thirtle's data set can be seen in Table 1D. Table 2D presents the shadow prices of public infrastructure and research by decade and their respective standard errors. The shadows for public infrastructure are significantly positive for all decades. Those for public R\&D are significantly positive from 1941 to 1950 , and from 1961 to 1980. These estimates support the first hypotheses of the theory. An interesting calculation here is possible. These results indicate that, on average, an additional dollar spent on public R\&D stocks will reduce costs by 6.5 dollars. If one assumes a thirty year impact of such an investment it means that one millon dollars of R\&D expenses have induced cost savings with a present value of 2.9 millions dollars, at a 5\% discount rate. This implies a rate of returns to public R\&D investments of $190 \%$. The same calculation for investments in

\footnotetext{
${ }^{27}$ Diewert and Wales (1987) show that, to impose those conditions globally, non-flexible functional forms must be adopted.

${ }^{28}$ A detailed explanation of this Bayesian estimation method is presented in Griffiths et al. (1999) and O'Donnell et al. (1999). Appendix 3 presents a brief description.
} 
public infrastructure give a far less impressive estimate of the rate of returns of approximately $1 \%$.

Tables 3D to 5D show the short- and long-run elasticities of demand and the elasticities of cost with respect to output. Estimates of the short-run elasticities of demand indicate that, in general, public inputs do not affect private inputs. Long-run estimates, however, show that both public infrastructure and public R\&D have had positive impacts on private capital accumulation, which is consistent with our hypothesis. Although these elasticities are significantly positive, they are very small. The larger estimated impact is in the 1981-1990 period: for every 10\% increase in the stock of public infrastructure or public R\&D, private capital increases about $0.35 \%$.

Finally, elasticities of cost with respect to output (second column of Table 5D) show that, except for the 1981-1990 period, the U.S. agricultural sector has exhibited increasing returns to scale in private inputs. That is, these elasticities are less than one even before adjusting for public inputs. This table also shows that additional units of infrastructure and R\&D decrease cost (third and fifth column of Table 5D). The cross elasticities between public inputs and output although not significantly different from zero, are of a very large magnitude. When they are used to calculate the augmented scale elasticity the results are inconsistent with economic theory as they indicate that additional output results on lower costs. Table 7 summarizes these results.

The MH estimation using Ball's data set was first done imposing the required conditions on all data points. In this case, no draw satisfying all the conditions could be obtained, i.e. the parameter space that satisfies the restrictions was empty. The conditions were then relaxed and, due to potential measurement errors, they were required to be satisfied only at $80 \%$ percent of the observations (Atkinson and Dorfman (2001)). Since this relaxation was not enough to get a nonempty set, the conditions implied by the Euler equations and adjustment costs were not imposed. ${ }^{29}$ Table 1B shows then the $\mathrm{MH}$ parameter estimates without imposing these two conditions.

As done with Ball's data set, Bayesian estimates of the parameters using Thirtle's data set were first obtained with imposition of all required conditions on all data points. In this case, no draw satisfying all the conditions could be obtained, i.e. the parameter space that satisfies the restrictions was again empty. The MH estimation was then relaxed by imposing only concavity of the value function and monotonicity in public inputs. Table 9 summarizes the violations by both set of estimates. ${ }^{30}$

\section{c. Results from other studies.}

A preliminary look at the results obtained by other researchers using similar procedures and data for U.S. agriculture indicate that Luh and Stefanou $(1991,1993)$ as well as Vasavada and Chambers, and Vasavada and Ball's estimates also reject the theoretical curvature conditions. It is not obvious in these papers what they find in terms of the monotonicity restrictions. Luh and Stefanou (1996) uses two data sets, one of which is a precursor of Ball's data set used in our paper, to test the hypotheses derived from a dynamic dual model with

\footnotetext{
${ }^{29}$ This was determined by trial and error examination of the conditions. It was found that the Euler equation and adjustment cost conditions were the conditions more difficult to be satisfied.

${ }^{30}$ Appendix 5 includes a discussion of other diagnostic tests run on these data as well as potential extensions of the analysis.
} 
non-static expectations. Tests of the properties of the value function estimated indicate rejection of monotonicity and curvature for both data sets, consistent with our results. They question the robustness of the aggregate data "to allow our models to capture the structure of the decision-making environment" (page 1002).

Among the concepts estimated by these authors, the relative speed of adjustment of the inputs to their long run steady state level is one we can readily compare to our results. Our results, as well as the results in all four papers mentioned indicate that capital adjusts faster than labor, as seen in Table 10.

Returns to scale can also be compared to the estimates in Luh and Stefanou (1991) and Luh and Stefanou (1993) having in mind that their estimates include disequilibrium terms while ours are at the steady state. In the first paper, these authors report decreasing returns to scale on private inputs in U.S. agriculture. In the second paper, that includes potential nonconvexities given by 'learning-by doing', they report decreasing returns evolving into increasing returns by the end of their data period. Maximum likelihood as well as Bayesian estimates from Ball's data set indicate decreasing returns to scale in both private only and private and public inputs. Maximum likelihood as well as the Bayesian estimates from Thirtle's data, estimate increasing returns from all factors, public and private, as well as for private factors. It should be noted that Luh and Stefanou's as well as our maximum likelihood estimates of scale are obtained from 'badly behaved' technologies.

\section{Conclusions}

This paper is an attempt to understand the impact of public R\&D and public infrastructure on the performance of the U.S. agricultural sector during the last part of the twentieth century. We ask if public policy could have been responsible for the sustained growth of the sector or if it just had a one time level effect. Given this sustained growth, a traditional neoclassical Solow growth model is not sufficient for the analysis. We have based our analysis on a well known endogenous growth model, the 'AK model' where nonconvexities are explained by the presence of non-rival inputs. We tried to keep true to the intrinsic nature of the growth process by using a dynamic model of behavior.

We have modeled the private decision making process when some private inputs are quasi-fixed and some inputs are public. In this context we have identified the conditions for sustained growth by deriving the impact of the non-rival inputs on the firm's objective (derivative property), on the dynamic demand for quasi-fixed factors (their steady state as well as their adjustment), and on returns to scale (extended Le Chatelier).

We have modeled the public decision making process in the provision of public inputs as that of a benevolent social planner whose objective is to maximize producers' surplus. We examined the behavioral properties implied by such model of public behavior and derived an optimal provision of public goods consistent with such an objective. We show that when the government maximizes intertemporal welfare by minimizing producers' cost it is possible to recover properties that characterized public behavior from those that characterize private behavior. We use these results to identify behavioral properties related to the rationality in the provision of public inputs, one of them being the expectation that endogenous prices for these 
inputs be non-negative. This is the property that, jointly with the derivative property of private decision makers, allows identification of the sign in this relationship to be used as a testable hypothesis.

In contrast to other studies (for instance, Nadiri and Mamuneas (1994) and Morrison and Schwartz (1996)), this paper rationalizes the public provision of non-rival inputs. Although Binswanger et al. (1993) and Huffman et al. (2002) have considered the public provision of infrastructure, they have done so using a static approach. The closest analysis, in spirit and method, would be that of Luh and Stefanou (1993) who introduced learning-bydoing as a source of growth in U.S. agriculture.

Theoretical analysis has allowed us to identify three behavioral hypotheses that are testable. They are: 1) increasing returns to scale over all inputs (private and public); 2) positive effect of additional units of public inputs on the long-run demand for private capital; and 3 ) negative impact of public inputs on cost.

These hypotheses were tested using two data sets for U.S. agriculture. One, covering the period 1948-1994, was developed by USDA following the guidelines of the AAEA taskforce on statistics with the objective of obtaining consistent indexes. The other, covering the period 1926-1990, was constructed by Thritle et al. A flexible functional form was adopted for the value function of the firm that included public inputs. The derived demand for two quasi-fixed factors, labor and private capital, and one variable factor, materials, were obtained and fitted using two different methods. These are a maximum likelihood estimator, the iterative non-linear seemingly unrelated procedure; and a Bayesian estimator from Griffith et al. (1999).

Using the parameters estimated the three hypotheses derived from the theory were tested. We learned that the maximum likelihood estimates from USDA's data set did not support any of the three hypotheses. We also learned that these estimates did not conform to the regularity nor behavioral conditions of the hypothesized behavior, rendering us unable to test the hypotheses. These results are consistent with those of other studies (Vasavada and Chambers, Vasavada and Ball, Luh and Stefanou (1996)) that have estimated dynamic (as well as static) behavior with aggregate data. The maximum likelihood estimates from Thirtle's data supported the first hypothesis, that of increasing returns to scale, but did not support the other two. These estimates also do not conform to the regularity and behavioral properties implied by economic theory.

We then used a Bayesian approach to impose some of the regularity and behavioral conditions on estimation. We relaxed the constraints that seemed binding, the Euler equation and the adjustment cost conditions. We learned that when using the USDA data set, only the third hypothesis was satisfied, indicating that additional units of $R \& D$ as well as public infrastructure have reduced private cost. It seems that for this aggregate data set we need to impose all the behavioral and regularity conditions to obtain meaningful estimates. These results support that of other studies (O'Donnell et al., O'Donnell) that have used this estimation approach with a static framework on some version of this data set. Bayesian estimates using Thirtle et al. data set seem consistent with all three hypotheses for endogenous growth in U.S. agriculture. That is, we find evidence of positive effects of public inputs on the steady state level of private capital, positive endogenous prices for R\&D and public infrastructure and increasing returns to scale. The estimate of return to scale, though, seems inconsistent with economic theory and intuition as it indicates, on average, a negative 
marginal cost. The estimates that support the third hypothesis, that of positive shadow prices for public inputs, give an interesting insight. They indicate that, on average, an additional dollar spent on public R\&D stocks will reduce costs by 6.5 dollars. This implies a rate of returns to public R\&D investments of $190 \%$. The same calculation for investments in public infrastructure gives a far less impressive estimate of the rate of returns of approximately $1 \%$.

A note of caution seems necessary. There are other theoretical, structural, and econometric modeling issues that we have not considered. We have not modeled expectations, nor uncertainty in the production process. We have not statistically tested for specification error. We have not checked for endogeneity of prices or output that might matter at this level of aggregation. We have not included private R\&D nor extension expenditures. We have not considered human capital formation as an external factor when we believe that it is probably one of the most important factors affecting growth of this sector. We have not attempted to follow our model more strictly by simultaneously estimating the full public decision process as well as the private decision process. A number of econometric issues were described in detail in Appendix 5.

It is important, though, to separate the theoretical from the econometric aspects of this paper. This paper has extended a well known endogenous growth model that explains sustained growth through provision of public R\&D and infrastructure, non-rival production inputs. The extension has been to model private and public behavior within a dynamic context so as to derive three testable hypotheses from the theory. These are derivations of general application. The theory was used to understand the role of public inputs on the sustained growth of the U.S. agricultural sector. In order to do so we use aggregates of outputs and inputs for the sector. We find some evidence of support of these hypotheses but we encounter a series of problems as estimates are not always consistent with the postulates of economic theory. In this sense this study supports the conclusions of many others that have used aggregate data to understand the decision making process. We join Luh and Stefanou (1996) in concluding that "Nevertheless, it is disturbing that two data series purporting to measure the production decisions by agents within the same sector present contradictory evidence..." 
Table $1 \mathrm{~A}$

Parameter Estimates, Ball's data set

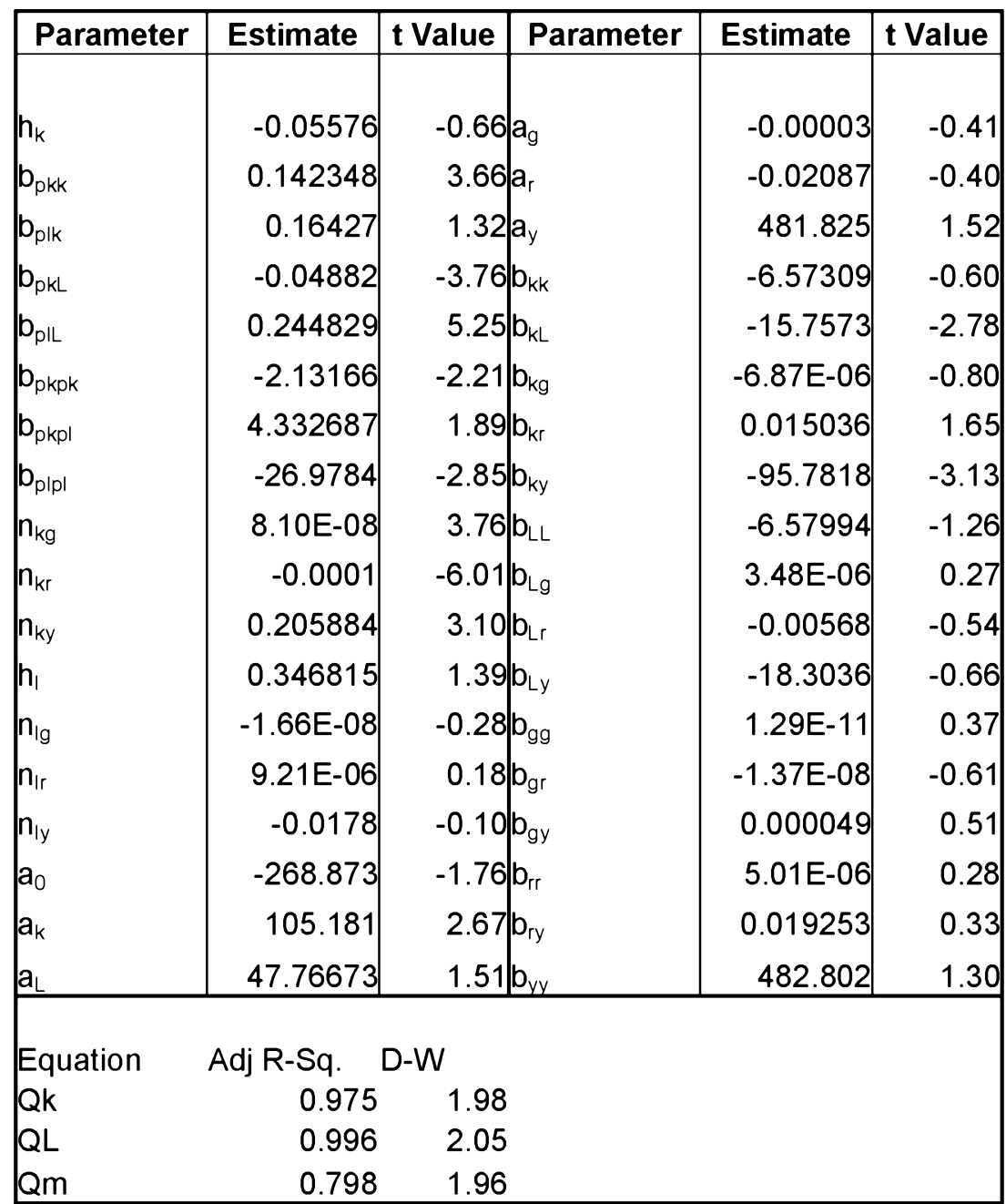

Table 2A

Shadow Prices based on ITSUR Estimates

Average By Decade, Ball's Data Set

\begin{tabular}{|l|r|r|}
\hline Decade & $\mathbf{P}^{*} \mathbf{g}$ & \multicolumn{1}{|c|}{$\mathbf{P}^{*} \mathbf{r}$} \\
\hline $1949-1959$ & $-4.00 \mathrm{E}-08$ & $8.68 \mathrm{E}-04$ \\
$1960-1969$ & $-3.40 \mathrm{E}-07$ & $7.15 \mathrm{E}-04$ \\
$1970-1979$ & $-8.20 \mathrm{E}-07$ & $8.08 \mathrm{E}-04$ \\
$1980-1989$ & $-1.29 \mathrm{E}-06$ & $1.35 \mathrm{E}-03$ \\
$1990-1994$ & $-1.15 \mathrm{E}-06$ & $1.42 \mathrm{E}-03$ \\
\hline $1949-1994$ & $-7.28 \mathrm{E}-07$ & $1.03 \mathrm{E}-03$ \\
\hline
\end{tabular}


Table 3A

Short-Run Elasticities of Demand for Private Inputs w/ Respect to Public Goods - ITSUR Estimates Average By Decade, Ball's Data Set

\begin{tabular}{|ccccccc|}
\hline Decade & $\mathrm{E}_{\mathrm{KG} \mathrm{SR}}$ & $\mathrm{E}_{\mathrm{KR} S \mathrm{SR}}$ & $\mathrm{E}_{\mathrm{LG} S \mathrm{SR}}$ & $\mathrm{E}_{\mathrm{LR} \mathrm{SR}}$ & $\mathrm{E}_{\mathrm{MG} S \mathrm{SR}}$ & $\mathrm{E}_{\mathrm{MR} S \mathrm{SR}}$ \\
\hline $1949-1959$ & -0.0032 & 0.00163 & 0.00573 & -0.00678 & -0.19251 & 0.34572 \\
$1960-1969$ & -0.00593 & 0.00229 & 0.01569 & -0.01409 & -0.34502 & 0.49375 \\
$1970-1979$ & -0.01534 & 0.00492 & 0.05827 & -0.04354 & -3.07294 & 5.80969 \\
$1980-1989$ & -0.03504 & 0.01594 & 0.16666 & -0.17651 & -1.70414 & 5.23461 \\
$1990-1994$ & -0.05688 & 0.03242 & 0.26842 & -0.35618 & -1.49635 & 3.71132 \\
\hline $1949-1994$ & -0.023278 & 0.01144 & 0.102954 & -0.11942 & -1.362192 & 3.119018 \\
\hline
\end{tabular}

Table 4A

Long-Run Elasticities of Demand for Private Inputs w/ Respect to Public Goods - ITSUR Estimates

Average By Decade

\begin{tabular}{|ccccccc|}
\hline Decade & $E_{\text {KG LR }}$ & $E_{\text {KR LR }}$ & $E_{L G ~ L R}$ & $E_{L R ~ L R}$ & $E_{M G ~ L R}$ & $E_{M R ~ L R}$ \\
\hline $1949-1959$ & -0.0052 & 0.0015 & -0.0494 & 0.0582 & -0.0542 & -0.377 \\
$1960-1969$ & -0.0093 & 0.0021 & -0.1214 & 0.1086 & 0.0562 & -0.1892 \\
$1970-1979$ & -0.0227 & 0.0042 & -0.469 & 0.3491 & 0.7331 & -0.3488 \\
$1980-1989$ & -0.0543 & 0.0143 & -1.0949 & 1.1555 & 1.798 & -1.3611 \\
$1990-1994$ & -0.0874 & 0.0289 & -1.7906 & 2.3675 & 2.4069 & -2.9955 \\
\hline $1949-1994$ & -0.03578 & 0.0102 & -0.70506 & 0.80778 & 0.988 & -1.05432 \\
\hline
\end{tabular}


Table 5A

Adjusted Elsticity of Cost with Respect to Output

ITSUR Estimates

Average By Decade, Ball's Data Set

\begin{tabular}{|ccccccc|}
\hline Decade & $\varepsilon_{\mathrm{cy}}$ & $\varepsilon_{\mathrm{cg}}$ & $\varepsilon_{\mathrm{gy}}$ & $\varepsilon_{\mathrm{cr}}$ & $\varepsilon_{\mathrm{ry}}$ & $\varepsilon_{\mathrm{cy}}^{\mathrm{A}}$ \\
\hline $1949-1959$ & 6.0191 & 0.0162 & -11.6249 & -0.3326 & -12.7337 & 10.0654 \\
$1960-1969$ & 3.3421 & 0.1955 & -7.1423 & -0.2877 & -10.2991 & 4.9092 \\
$1970-1979$ & 1.6886 & 0.9398 & -3.0628 & -0.5372 & -5.3083 & 1.6617 \\
$1980-1989$ & 2.9251 & 2.7906 & -1.6174 & -2.4054 & -1.9774 & 3.168 \\
$1990-1994$ & 5.0124 & 4.2069 & -1.3134 & -5.3131 & -1.2816 & 6.2965 \\
\hline $1949-1994$ & 3.79746 & 1.6298 & -4.95216 & -1.7752 & -6.32002 & 5.22016 \\
\hline
\end{tabular}


Table 1B

Bayesian Parameter Estimates, Ball's Data Set

\begin{tabular}{|lrr|lrr|}
\hline Parameter & Estimate & \multicolumn{1}{l|}{$\mathrm{t}$ Value } & Parameter & Estimate & \multicolumn{1}{c|}{$\mathrm{t}$ Value } \\
\hline hk & & & & & \\
bpkk & -0.05068 & -2.06 & ag & 0.000032 & 1.76 \\
bplk & 0.252834 & 13.34 & ar & -0.01231 & -1.19 \\
bpkL & -0.05284 & -16.27 & ay & -259.881 & -1.70 \\
bplL & 0.415566 & 2.89 & bkk & -0.8161 & -0.37 \\
bpkpk & 0.178916 & 6.93 & bkL & 2.563959 & 1.84 \\
bpkpl & -1.49199 & -2.12 & bkg & $2.41 \mathrm{E}-06$ & 0.92 \\
bplpl & 4.119652 & 5.28 & bkr & -0.00177 & -0.80 \\
nkg & -38.4536 & -5.33 & bky & 15.13473 & 1.68 \\
nkr & $-1.27 \mathrm{E}-09$ & -0.22 & bLL & 1.751193 & 0.90 \\
nky & $2.63 \mathrm{E}-06$ & 0.59 & bLg & -0.00001 & -1.83 \\
hl & -0.0221 & -2.75 & bLr & 0.009502 & 1.90 \\
nlg & 0.612025 & 3.33 & bLy & 20.56857 & 1.31 \\
nlr & $3.80 \mathrm{E}-09$ & 0.19 & bgg & $2.77 \mathrm{E}-11$ & 1.79 \\
nly & $-3.5 \mathrm{E}-05$ & -1.41 & bgr & $-8.65 \mathrm{E}-08$ & -9.44 \\
a0 & 0.155178 & 2.19 & bgy & -0.00002 & -1.55 \\
ak & 134.2401 & 1.59 & brr & $8.61 \mathrm{E}-06$ & 1.97 \\
aL & -19.6675 & -1.88 & bry & -0.00926 & -1.02 \\
\hline
\end{tabular}

Table 2B

Shadow Prices of Public Inputs

Bayesian Estimates

Average By Decade, Ball's Data Set

\begin{tabular}{|r|r|r|}
\hline Decade & \multicolumn{1}{|c|}{$\mathrm{P}^{*} \mathrm{~g}$} & \multicolumn{1}{c|}{$\mathrm{P}{ }^{\mathrm{r}}$} \\
\hline \multirow{3}{*}{$1949-1959$} & $8.00 \mathrm{E}-07$ & $4.38 \mathrm{E}-04$ \\
& $(-2.00 \mathrm{E}-07)$ & $(-2.29 \mathrm{E}-04)$ \\
$1960-1969$ & $5.00 \mathrm{E}-07$ & $1.43 \mathrm{E}-03$ \\
& $(-3.00 \mathrm{E}-07)$ & $(-2.05 \mathrm{E}-04)$ \\
$1970-1979$ & $1.00 \mathrm{E}-06$ & $4.40 \mathrm{E}-03$ \\
& $(-6.00 \mathrm{E}-07)$ & $(-4.76 \mathrm{E}-04)$ \\
$1980-1989$ & $4.80 \mathrm{E}-06$ & $9.48 \mathrm{E}-03$ \\
& $(-1.10 \mathrm{E}-06)$ & $(-9.77 \mathrm{E}-04)$ \\
$1990-1994$ & $9.80 \mathrm{E}-06$ & $1.32 \mathrm{E}-02$ \\
& $(-1.20 \mathrm{E}-06)$ & $(-1.31 \mathrm{E}-03)$ \\
\hline $1949-1994$ & $3.38 \mathrm{E}-06$ & $5.78 \mathrm{E}-03$ \\
& & \\
\hline
\end{tabular}


Table 3B

Short-Run Elasticities of Demand for Private Inputs w/ Respect to Public Goods - Bayesian Estimation Average By Decade, Ball's Data Set

\begin{tabular}{|c|c|c|c|c|c|c|}
\hline Decade & $\mathrm{E}_{\mathrm{KG} \_\mathrm{SR}}$ & $\mathrm{E}_{\mathrm{KR} \_\mathrm{SR}}$ & $\mathrm{E}_{\mathrm{LG} \_\mathrm{SR}}$ & $\mathrm{E}_{\mathrm{LR} \_\mathrm{SR}}$ & $\mathrm{E}_{\mathrm{MG} \_\mathrm{SR}}$ & $\mathrm{E}_{\mathrm{MR} \_\mathrm{SR}}$ \\
\hline 1949-1959 & $\begin{array}{c}0.001024 \\
(0.004361)\end{array}$ & $\begin{array}{c}-0.00314 \\
(0.004948)\end{array}$ & $\begin{array}{c}-0.000064 \\
(0.000521)\end{array}$ & $\begin{array}{c}0.000209 \\
(0.000369)\end{array}$ & $\begin{array}{c}-0.055511 \\
(1.911529)\end{array}$ & $\begin{array}{c}0.0165787 \\
(1.6393535)\end{array}$ \\
\hline 1960-1969 & $\begin{array}{c}0.001571 \\
(0.008291)\end{array}$ & $\begin{array}{c}-0.010085 \\
(0.007133)\end{array}$ & $\begin{array}{c}-0.000274 \\
(0.001304)\end{array}$ & $\begin{array}{c}0.000395 \\
(0.000703)\end{array}$ & $\begin{array}{c}0.227909 \\
(0.665811)\end{array}$ & $\begin{array}{c}-0.201544 \\
(0.4454666)\end{array}$ \\
\hline 1970-1979 & $\begin{array}{c}0.004234 \\
(0.022389)\end{array}$ & $\begin{array}{c}-0.022613 \\
(0.016082)\end{array}$ & $\begin{array}{c}-0.000945 \\
(0.004381)\end{array}$ & $\begin{array}{c}0.001136 \\
(0.001967)\end{array}$ & $\begin{array}{c}0.351909 \\
(0.437095)\end{array}$ & $\begin{array}{c}-0.398083 \\
(0.2141283)\end{array}$ \\
\hline $1980-1989$ & $\begin{array}{c}0.009688 \\
(0.051173)\end{array}$ & $\begin{array}{c}-0.073346 \\
(0.052028)\end{array}$ & $\begin{array}{c}-0.002552 \\
(0.011634)\end{array}$ & $\begin{array}{c}0.004348 \\
(0.007419)\end{array}$ & $\begin{array}{c}0.319634 \\
(1.412777)\end{array}$ & $\begin{array}{c}-2.875702 \\
(0.7075312)\end{array}$ \\
\hline 1990-1994 & $\begin{array}{c}0.01524 \\
(0.080443)\end{array}$ & $\begin{array}{c}-0.144549 \\
(0.102555) \\
\end{array}$ & $\begin{array}{c}-0.004074 \\
(0.018737) \\
\end{array}$ & $\begin{array}{c}0.008698 \\
(0.014966) \\
\end{array}$ & $\begin{array}{c}1.854532 \\
(2.526301) \\
\end{array}$ & $\begin{array}{c}7.7162574 \\
(2.3555209) \\
\end{array}$ \\
\hline 1949-1994 & 0.0063514 & -0.0507466 & -0.0015818 & 0.0029572 & 0.5396946 & 0.8515014 \\
\hline
\end{tabular}

Table 4B

Long-Run Elasticities of Demand for Private Inputs w/ Respect to Public Goods - Bayesian Estimation Average By Decade, Ball's Data Set

\begin{tabular}{|c|cccccc|}
\hline Decade & $E_{K_{-} L R}$ & $E_{K_{-} L R}$ & $E_{L_{-} L R}$ & $E_{L_{-} L R}$ & $E_{M_{-} L R}$ & $E_{M_{-} L R}$ \\
\hline \multirow{4}{*}{$1949-1959$} & 0.002857 & -0.00876 & 0.000498 & -0.00163 & -0.01863 & -0.01004 \\
& $(0.00027)$ & $(0.000829)$ & $(1.65 E-05)$ & $(5.38 E-05)$ & $(0.004214)$ & $(0.004425)$ \\
& & & & & & \\
$1960-1969$ & 0.002366 & -0.01567 & 0.001421 & -0.00252 & -0.01692 & -0.03368 \\
& $(0.000284)$ & $(0.001882)$ & $(3.88 E-05)$ & $(6.87 E-05)$ & $(0.009149)$ & $(0.004084)$ \\
$1970-1979$ & 0.006648 & -0.03662 & 0.00399 & -0.00588 & -0.06431 & -0.17719 \\
& $(0.000803)$ & $(0.004426)$ & $(0.000134)$ & $(0.000198)$ & $(0.043828)$ & $(0.016638)$ \\
$1980-1989$ & 0.016232 & -0.12677 & 0.00912 & -0.01906 & -1.1995 & -2.01438 \\
& $(0.002087)$ & $(0.016297)$ & $(0.000295)$ & $(0.000617)$ & $(0.34993)$ & $(0.200925)$ \\
$1990-1994$ & 0.022502 & -0.22018 & 0.015937 & -0.04173 & 4.580564 & 6.403403 \\
& $(0.001775)$ & $(0.017371)$ & $(0.000547)$ & $(0.001433)$ & $(1.311022)$ & $(1.783446)$ \\
\hline $1949-1994$ & 0.010121 & -0.0816 & 0.0061932 & -0.014164 & 0.6562408 & 0.8336226 \\
& & & & & & \\
\hline
\end{tabular}


Table 5B

Adjusted Elsticity of Cost with Respect to Output - Bayesian Estimation Average By Decade, Ball's Data Set

\begin{tabular}{|c|cccccc|}
\hline Decade & $\varepsilon_{\mathrm{cy}}$ & $\varepsilon_{\mathrm{cg}}$ & $\varepsilon_{\mathrm{gy}}$ & $\varepsilon_{\mathrm{cr}}$ & $\varepsilon_{\mathrm{ry}}$ & $\varepsilon_{\mathrm{cy}}^{\mathrm{A}}$ \\
\hline \multirow{4}{*}{$1949-1959$} & 2.08066 & -0.01931 & 17.12097 & -0.00999 & 0.74827 & 1.74257 \\
& $(0.088874)$ & $(0.005226)$ & $(11.76344)$ & $(0.005263)$ & $(39.3168)$ & $(0.444036)$ \\
$1960-1969$ & 2.278679 & -0.02102 & 1.315998 & -0.03838 & 2.884776 & 2.140291 \\
& $(0.112834)$ & $(0.009346)$ & $(7.227383)$ & $(0.005559)$ & $(31.79968)$ & $(1.553354)$ \\
$1970-1979$ & 2.581448 & -0.07948 & 0.564339 & -0.20971 & 1.486848 & 2.224795 \\
& $(0.155223)$ & $(0.048143)$ & $(3.099318)$ & $(0.028902)$ & $(16.38993)$ & $(3.945232)$ \\
$1980-1989$ & 10.46272 & -2.54554 & 0.298008 & -4.15066 & 0.553867 & 7.405213 \\
& $(40.29378)$ & $(13.01153)$ & $(1.63664)$ & $(15.19929)$ & $(6.105425)$ & $(93.66995)$ \\
$1990-1994$ & -5.87366 & 3.100688 & 0.241997 & 4.283043 & 0.358983 & -3.58576 \\
& $(0.954618)$ & $(0.679007)$ & $(1.329035)$ & $(0.609656)$ & $(3.95717)$ & $(17.70768)$ \\
\hline $1049-1994$ & 2.3059694 & 0.0870676 & 3.9082624 & -0.0251394 & 1.2065488 & 1.9854218 \\
& & & & & & \\
\hline
\end{tabular}


Table 1C

Parameter Estimates, Thirtle Data Set

\begin{tabular}{|c|c|c|c|c|c|}
\hline Parameter & Estimate & t Value & Parameter & Estimate & t Value \\
\hline$h_{k}$ & 0.001417 & 0.04 & $g$ & 0.00002 & 0.3 \\
\hline$b_{p k k}$ & -0.04502 & -1.72 & ir & -0.05677 & -0.76 \\
\hline$b_{p l k}$ & 0.008142 & 1.13 & $y$ & 6.531807 & 0.08 \\
\hline$b_{p k L}$ & 0.239427 & 2.25 & $b_{k k}$ & -86.4016 & -3.49 \\
\hline$b_{\mathrm{plL}}$ & 0.096236 & 2.31 & $\mathrm{~kL}$ & -2.65944 & -0.52 \\
\hline$b_{p k p k}$ & 25.33993 & 3.03 & $\mathrm{~kg}$ & 0.000087 & 2.22 \\
\hline$b_{p k p l}$ & -19.093 & -2.01 & $\mathrm{kr}$ & -0.07408 & -1.81 \\
\hline$b_{p|p|}$ & 0.192109 & 0.04 & oky & -20.418 & -0.75 \\
\hline$n_{\mathrm{kg}}$ & $4.55 E-08$ & 2.96 & LL & 1.130363 & 0.58 \\
\hline$n_{k r}$ & -0.00013 & -4.54 & Lg & 8.44E-06 & 0.91 \\
\hline$n_{k y}$ & -0.02782 & -1.1 & $\mathrm{Lr}$ & -0.00531 & -0.49 \\
\hline$h_{1}$ & 0.171812 & 0.78 & Ly & -2.48711 & -0.31 \\
\hline$n_{1 g}$ & $6.24 \mathrm{E}-08$ & 0.92 & gg & $1.74 \mathrm{E}-10$ & 2.55 \\
\hline$n_{1 r}$ & -0.00016 & -1.28 & gr & $-3.32 E-07$ & -2.41 \\
\hline$n_{1 y}$ & 0.152884 & 1.09 & $b_{g y}$ & -0.00004 & -0.73 \\
\hline$a_{0}$ & -20.8604 & -0.46 & $b_{\text {гr }}$ & 0.000489 & 2.06 \\
\hline$a_{k}$ & 78.63147 & 2.14 & $b_{\text {ry }}$ & 0.098347 & 1.31 \\
\hline$a_{L}$ & -0.62287 & -0.05 & $b_{y y}$ & 2.780143 & 0.03 \\
\hline Equation & \multicolumn{5}{|l|}{ Adj R-Sq. } \\
\hline Qk & 0.9918 & 1.4279 & & & \\
\hline QL & 0.9950 & 2.7824 & & & \\
\hline Qm & 0.9950 & 1.9383 & & & \\
\hline
\end{tabular}

Note: Bold numbers indicate parameter estimates that are significant at the $95 \%$ confidence level; Italic numbers indicate significance at the $90 \%$ level.

Table 2C

Shadow Prices based on ITSUR Estimates Average By Decade, Thirtle's Data Set

\begin{tabular}{|c|c|c|}
\hline Decade & $P^{\star} g$ & $P^{\star} r$ \\
\hline $1926-1930$ & $-4.24 \mathrm{e}-6$ & 0.00463 \\
$1931-1940$ & $-3.989 \mathrm{e}-6$ & 0.00443 \\
$1941-1950$ & $-2.935 \mathrm{e}-6$ & 0.00246 \\
$1951-1960$ & $-1.172 \mathrm{e}-6$ & -0.00156 \\
$1961-1970$ & $-6.412 \mathrm{e}-7$ & 0.00037 \\
$1971-1980$ & $-4.753 \mathrm{e}-6$ & 0.00951 \\
$1981-1990$ & $-4.249 \mathrm{e}-6$ & 0.01399 \\
\hline $1926-1990$ & $-3.145 \mathrm{e}-6$ & 0.00594 \\
\hline
\end{tabular}


Table 3C

Short-Run Elasticities of Demand for Private Inputs

w/ Respect to Public Goods - ITSUR Estimates

Average By Decade, Thirtle's Data Set

\begin{tabular}{|ccccccc|}
\hline Decade & $\mathrm{E}_{\mathrm{KG} \_\mathrm{SR}}$ & $\mathrm{E}_{\mathrm{KR} \_\mathrm{SR}}$ & $\mathrm{E}_{\mathrm{LG} \_\mathrm{SR}}$ & $\mathrm{E}_{\mathrm{LR} \_\mathrm{SR}}$ & $\mathrm{E}_{\mathrm{MG} \_\mathrm{SR}}$ & $\mathrm{E}_{\mathrm{MR} \_\mathrm{SR}}$ \\
\hline $1926-1930$ & 0.0033 & -0.0123 & 0.0006 & -0.0025 & 2.2684 & -2.9337 \\
$1931-1940$ & 0.0045 & -0.0154 & 0.0008 & -0.0032 & 1.1682 & -1.3785 \\
$1941-1950$ & 0.0081 & -0.0300 & 0.0021 & -0.0085 & -0.8034 & 1.0344 \\
$1951-1960$ & 0.0126 & -0.0635 & 0.0057 & -0.0318 & -0.4568 & 0.8156 \\
$1961-1970$ & 0.0250 & -0.0725 & 0.0164 & -0.0534 & -1.3846 & 1.4364 \\
$1971-1980$ & 0.0626 & -0.0883 & 0.0625 & -0.0990 & 7.4667 & -3.9203 \\
$1981-1990$ & 0.1397 & -0.1940 & 0.1597 & -0.2488 & 2.9476 & -1.4184 \\
\hline $\mathbf{1 9 2 6 - 1 9 9 0}$ & 0.0453 & -0.0809 & 0.0188 & -0.0377 & 38.5343 & -24.2119 \\
\hline
\end{tabular}

Table 4C

Long-Run Elasticities of Demand for Private Inputs

w/ Respect to Public Goods - ITSUR Estimates

Average By Decade, Thirtle's Data Set

\begin{tabular}{|c|c|c|c|c|c|c|}
\hline Decade & $E_{\text {KG_LR }}$ & $E_{\text {KR_LR }}$ & $\mathrm{E}_{\mathrm{LG}_{-} \mathrm{LR}}$ & $\mathrm{E}_{\mathrm{LR} \_\mathrm{LR}}$ & $E_{\text {MG_LR }}$ & $E_{\text {MR_LR }}$ \\
\hline $1926-1930$ & 0.0054 & -0.0204 & 0.0212 & -0.0889 & 1.1519 & -1.3853 \\
\hline $1931-1940$ & 0.0068 & -0.0233 & 0.0278 & -0.1066 & 1.4335 & -1.5682 \\
\hline $1941-1950$ & 0.0144 & -0.0534 & 0.0764 & -0.3169 & 2.7147 & -1.6468 \\
\hline $1951-1960$ & 0.0204 & -0.1030 & 0.4183 & -2.3584 & -0.3330 & 3.5833 \\
\hline $1961-1970$ & 0.0374 & -0.1088 & 0.7765 & -2.5291 & -0.2777 & 1.5915 \\
\hline $1971-1980$ & 0.0995 & -0.1409 & 1.3877 & -2.1984 & 1.9316 & -1.7625 \\
\hline $1981-1990$ & 0.1626 & -0.2260 & -15.3559 & 23.9349 & 8.9254 & -21.2764 \\
\hline $1926-1990$ & 0.0669 & -0.1200 & 0.8779 & -1.7622 & 1.2033 & -0.8793 \\
\hline
\end{tabular}


Table 5C

Adjusted Elsticity of Cost with Respect to Output

ITSUR Estimates

Average By Decade, Thirtle's Data Set

\begin{tabular}{|c|llllll|}
\hline Decade & $\varepsilon_{\mathrm{cy}}$ & $\varepsilon_{\mathrm{cg}}$ & $\varepsilon_{\mathrm{gy}}$ & $\varepsilon_{\mathrm{cr}}$ & $\varepsilon_{\mathrm{ry}}$ & $\varepsilon_{\mathrm{cy}}^{\mathrm{A}}$ \\
\hline $\mathbf{1 9 2 6 - 1 9 3 0}$ & 0.1609 & 0.0539 & 3.6807 & -0.0882 & -1.9975 & 0.5353 \\
$\mathbf{1 9 3 1 - 1 9 4 0}$ & 0.1881 & 0.0683 & 2.8203 & -0.1038 & -1.6740 & 0.5544 \\
$1941-1950$ & 0.2206 & 0.1149 & 1.6876 & -0.1423 & -0.9273 & 0.5465 \\
$1951-1960$ & 0.5029 & 0.0068 & 1.0187 & 0.1806 & -0.4115 & 0.4355 \\
$1961-1970$ & 0.5002 & 0.0469 & 0.6079 & -0.0314 & -0.4251 & 0.5420 \\
$1971-1980$ & 0.3892 & 0.5320 & 0.2539 & -0.6017 & -0.3651 & 0.7440 \\
$1981-1990$ & 0.6525 & 0.9919 & 0.1363 & -1.8172 & -0.1992 & 1.1497 \\
\hline $\mathbf{1 9 2 6 - 1 9 9 0}$ & 0.3642 & 0.3009 & 0.3323 & -0.3767 & -0.3771 & 0.6062 \\
\hline & & & & & &
\end{tabular}


Table 10

Bayesian Parameter Estimates, Thirtle's Data Set

\begin{tabular}{|lrr|lrr|}
\hline Parameter & Estimate & t Value & Parameter & Estimate & t Value \\
\hline hk & $\mathbf{0 . 1 0 6 6 2 3 5}$ & 31.48 & ag & $\mathbf{- 0 . 0 0 0 0 2 4}$ & -6.15 \\
bpkk & $\mathbf{0 . 1 0 0 9 1 8 3}$ & 26.22 & ar & $\mathbf{0 . 0 1 5 3 2 1 5}$ & 1.94 \\
bplk & $\mathbf{0 . 0 1 2 0 1 4 4}$ & 13.63 & ay & $\mathbf{1 5 . 4 3 2 7 1 2}$ & 1.84 \\
bpkL & $\mathbf{0 . 0 1 9 2 1 8 3}$ & 11.03 & bkk & 6.8358263 & 0.89 \\
bplL & $\mathbf{0 . 1 1 9 3 4 4 7}$ & 13.27 & bkL & 0.7282358 & 0.99 \\
bpkpk & $\mathbf{- 2 . 6 9 9 5 5 9}$ & -1.80 & bkg & $-1.83 E-06$ & -0.35 \\
bpkpl & 1.2181477 & 1.53 & bkr & 0.0000836 & 0.03 \\
bplpl & $\mathbf{- 0 . 9 6 0 2 5 5}$ & -2.36 & bky & 2.5991692 & 0.65 \\
nkg & $-7.86 E-10$ & -0.46 & bLL & $\mathbf{- 0 . 8 8 6 1 2 1}$ & -2.76 \\
nkr & $-2.82 E-06$ & -0.64 & bLg & $\mathbf{1 . 2 0 E - 0 6}$ & 2.43 \\
nky & -0.00021 & -0.06 & bLr & $\mathbf{- 0 . 0 0 3 0 9 1}$ & -1.97 \\
hl & 0.0298721 & 0.59 & bLy & -0.397538 & -0.55 \\
nlg & $-5.85 E-09$ & -1.26 & bgg & $\mathbf{- 1 . 4 0 E - 1 1}$ & -1.90 \\
nlr & -0.00001 & -0.64 & bgr & $-1.39 E-09$ & -0.18 \\
nly & $\mathbf{0 . 0 9 2 9 9 8 8}$ & 2.05 & bgy & $\mathbf{0 . 0 0 0 0 2 9 9}$ & 5.75 \\
a0 & $\mathbf{3 6 . 3 6 4 9 0 2}$ & 7.60 & brr & $\mathbf{8 . 5 1 E - 0 7}$ & 0.08 \\
ak & $\mathbf{- 1 4 . 3 2 0 8 6}$ & -1.65 & bry & $\mathbf{- 0 . 0 1 3 8 8}$ & -1.90 \\
aL & $\mathbf{- 3 . 7 9 9 9 3 2}$ & -3.03 & byy & -5.387139 & -0.51 \\
\hline
\end{tabular}

Note: Bold numbers indicate parameter estimates that are significant at the $95 \%$ confidence level.

Table 2D

Shadow Prices of Public Inputs

Bayesian Estimates

Average By Decade, Thirtle's Data Set

\begin{tabular}{|c|c|c|}
\hline Decade & $P^{\star} g$ & $P^{*} r$ \\
\hline $1926-1930$ & $\begin{array}{r}0.00000029 \\
(0.0000001)\end{array}$ & $\begin{array}{r}0.0001360 \\
(0.0000874)\end{array}$ \\
\hline 1931-1940 & $\begin{array}{r}\mathbf{0 . 0 0 0 0 0 0 3 0} \\
(0.0000001)\end{array}$ & $\begin{array}{r}0.0000971 \\
(0.0000692)\end{array}$ \\
\hline 1941-1950 & $\begin{array}{r}\mathbf{0 . 0 0 0 0 0 0 1 5} \\
(0.00000005)\end{array}$ & $\begin{array}{r}0.0001746 \\
(0.0000853)\end{array}$ \\
\hline $1951-1960$ & $\begin{array}{r}\mathbf{0 . 0 0 0 0 0 0 1 3} \\
(0.0000001)\end{array}$ & $\begin{array}{r}0.0001343 \\
(0.0000886)\end{array}$ \\
\hline $1961-1970$ & $\begin{array}{r}0.00000011 \\
(0.0000001)\end{array}$ & $\begin{array}{r}\mathbf{0 . 0 0 0 1 6 6 5} \\
(0.0000741)\end{array}$ \\
\hline $1971-1980$ & $\begin{array}{r}0.00000040 \\
(0.0000002)\end{array}$ & $\begin{array}{r}\mathbf{0 . 0 0 0 3 2 2 5} \\
(0.0001730)\end{array}$ \\
\hline $1981-1990$ & $\begin{array}{r}0.00000112 \\
(0.0000004)\end{array}$ & $\begin{array}{r}0.0004988 \\
(0.0004166)\end{array}$ \\
\hline $1926-1990$ & $\begin{array}{r}\mathbf{0 . 0 0 0 0 0 0 3 7} \\
(0.0000001)\end{array}$ & $\begin{array}{r}\mathbf{0 . 0 0 0 2 4 1 5} \\
(0.0000669)\end{array}$ \\
\hline
\end{tabular}

Note: Standard Deviations between parentheses;

Bold numbers indicate significance at the $95 \%$ confidence level. 
Table 3D

Short-Run Elasticities of Demand for Private Inputs

w/ Respect to Public Goods - Bayesian Estimation Average By Decade, Thirtle's Data Set

\begin{tabular}{|c|c|c|c|c|c|c|}
\hline Decade & $\mathrm{E}_{\mathrm{KG} \_\mathrm{SR}}$ & $\mathrm{E}_{\mathrm{KR} \_\mathrm{SR}}$ & $\mathrm{E}_{\mathrm{LG} \_\mathrm{SR}}$ & $\mathrm{E}_{\mathrm{LR} \_\mathrm{SR}}$ & $\mathrm{E}_{\mathrm{MG} \_\mathrm{SR}}$ & $\mathrm{E}_{\mathrm{MR} \_\mathrm{SR}}$ \\
\hline $1926-1930$ & $\begin{array}{r}-0.000303 \\
(0.000241)\end{array}$ & $\begin{array}{r}-0.000788 \\
(0.001239)\end{array}$ & $\begin{array}{r}-0.000008 \\
(0.000018)\end{array}$ & $\begin{array}{r}-0.000045 \\
(0.000071)\end{array}$ & $\begin{array}{r}-0.025297 \\
(0.015556)\end{array}$ & $\begin{array}{r}-0.087616 \\
(0.104375)\end{array}$ \\
\hline 1931-1940 & $\begin{array}{r}-0.000405 \\
(0.000321)\end{array}$ & $\begin{array}{r}-0.000963 \\
(0.001515)\end{array}$ & $\begin{array}{r}-0.000012 \\
(0.000026)\end{array}$ & $\begin{array}{r}-0.000059 \\
(0.000092)\end{array}$ & $\begin{array}{r}-0.021028 \\
(0.006811)\end{array}$ & $\begin{array}{r}-0.051758 \\
(0.045632)\end{array}$ \\
\hline $1941-1950$ & $\begin{array}{r}-0.000746 \\
(0.000593)\end{array}$ & $\begin{array}{r}-0.001917 \\
(0.003015)\end{array}$ & $\begin{array}{r}-0.000030 \\
(0.000065)\end{array}$ & $\begin{array}{r}-0.000159 \\
(0.000248)\end{array}$ & $\begin{array}{r}-0.012243 \\
(0.006200)\end{array}$ & $\begin{array}{r}-0.064362 \\
(0.040911)\end{array}$ \\
\hline $1951-1960$ & $\begin{array}{r}-0.001158 \\
(0.000920)\end{array}$ & $\begin{array}{r}-0.004048 \\
(0.006368)\end{array}$ & $\begin{array}{r}-0.000084 \\
(0.000182)\end{array}$ & $\begin{array}{r}-0.000605 \\
(0.000944)\end{array}$ & $\begin{array}{r}-0.018778 \\
(0.008694)\end{array}$ & $\begin{array}{r}-0.047929 \\
(0.034736)\end{array}$ \\
\hline 1961-1970 & $\begin{array}{r}-0.002276 \\
(0.001807)\end{array}$ & $\begin{array}{r}-0.004594 \\
(0.007228)\end{array}$ & $\begin{array}{r}-0.000259 \\
(0.000563)\end{array}$ & $\begin{array}{r}-0.001079 \\
(0.001684)\end{array}$ & $\begin{array}{r}-0.024622 \\
(0.016521)\end{array}$ & $\begin{array}{r}-0.007244 \\
(0.024703)\end{array}$ \\
\hline $1971-1980$ & $\begin{array}{r}-0.005817 \\
(0.004617)\end{array}$ & $\begin{array}{r}-0.005711 \\
(0.008985)\end{array}$ & $\begin{array}{r}-0.001105 \\
(0.002420)\end{array}$ & $\begin{array}{r}-0.002239 \\
(0.003496)\end{array}$ & $\begin{array}{r}-0.214746 \\
(0.088516)\end{array}$ & $\begin{array}{r}-0.012528 \\
(0.083936)\end{array}$ \\
\hline 1981-1990 & $\begin{array}{r}-0.012533 \\
(0.009934)\end{array}$ & $\begin{array}{r}-0.012106 \\
(0.019047)\end{array}$ & $\begin{array}{r}-0.002959 \\
(0.006477)\end{array}$ & $\begin{array}{r}-0.005898 \\
(0.009205)\end{array}$ & $\begin{array}{r}-\mathbf{1 . 5 0 5 9 0 4} \\
(0.566352)\end{array}$ & $\begin{array}{r}-0.125753 \\
(0.403862)\end{array}$ \\
\hline 1926-1990 & $\begin{array}{r}-0.004123 \\
(0.003272)\end{array}$ & $\begin{array}{r}-0.005129 \\
(0.008069)\end{array}$ & $\begin{array}{r}-0.000284 \\
(0.000616)\end{array}$ & $\begin{array}{r}-0.000728 \\
(0.001137)\end{array}$ & $\begin{array}{r}-0.157398 \\
(0.042998)\end{array}$ & $\begin{array}{r}-\mathbf{0 . 0 7 1 4 9} \\
(0.014500)\end{array}$ \\
\hline
\end{tabular}

Note: Standard Deviations between parentheses; Bold numbers indicate significance at the $95 \%$ confidence level. 
Table 4D

Long-Run Elasticities of Demand for Private Inputs

w/ Respect to Public Goods- Bayesian Estimation

Average By Decade, Thirtle's Data Set

\begin{tabular}{|c|c|c|c|c|c|c|}
\hline Decade & $E_{K G \_L R}$ & $\mathrm{E}_{\mathrm{KR} \_\mathrm{LR}}$ & $E_{L_{G} L R}$ & $E_{L_{R} L R}$ & $E_{\text {MG_LR }}$ & $\mathrm{E}_{\mathrm{MR} \_\mathrm{LR}}$ \\
\hline $1926-1930$ & $\begin{array}{r}\mathbf{0 . 0 0 0 3 9 9} \\
(0.000035)\end{array}$ & $\begin{array}{r}\mathbf{0 . 0 0 1 0 3 6} \\
(0.000092)\end{array}$ & $\begin{array}{r}0.000249 \\
(0.000443)\end{array}$ & $\begin{array}{r}0.001383 \\
(0.002465)\end{array}$ & $\begin{array}{r}-0.010098 \\
(0.002184)\end{array}$ & $\begin{array}{r}-0.006118 \\
(0.004153)\end{array}$ \\
\hline $1931-1940$ & $\begin{array}{r}\mathbf{0 . 0 0 0 5 2 7} \\
(0.000046)\end{array}$ & $\begin{array}{r}\mathbf{0 . 0 0 1 2 5 0} \\
(0.000109)\end{array}$ & $\begin{array}{c}0.000324 \\
(0.000515)\end{array}$ & $\begin{array}{r}0.001647 \\
(0.002619)\end{array}$ & $\begin{array}{r}-0.012911 \\
(0.002531)\end{array}$ & $\begin{array}{r}-0.004716 \\
(0.003907)\end{array}$ \\
\hline $1941-1950$ & $\begin{array}{r}\mathbf{0 . 0 0 1 1 7 7} \\
(0.000081)\end{array}$ & $\begin{array}{r}\mathbf{0 . 0 0 3 0 1 6} \\
(0.000208)\end{array}$ & $\begin{array}{r}\mathbf{0 . 0 0 0 5 3 3} \\
(0.000174)\end{array}$ & $\begin{array}{r}\mathbf{0 . 0 0 2 9 2 6} \\
(0.000956)\end{array}$ & $\begin{array}{r}-0.010616 \\
(0.004750)\end{array}$ & $\begin{array}{r}-\mathbf{0 . 0 1 6 4 3 5} \\
(0.009278)\end{array}$ \\
\hline $1951-1960$ & $\begin{array}{r}\mathbf{0 . 0 0 2 3 5 8} \\
(0.000113)\end{array}$ & $\begin{array}{r}\mathbf{0 . 0 0 8 2 1 7} \\
(0.000392)\end{array}$ & $\begin{array}{r}\mathbf{0 . 0 0 0 8 9 0} \\
(0.000170)\end{array}$ & $\begin{array}{r}\mathbf{0 . 0 0 6 6 5 1} \\
(0.001268)\end{array}$ & $\begin{array}{r}-0.013925 \\
(0.010286)\end{array}$ & $\begin{array}{r}-0.022051 \\
(0.025800)\end{array}$ \\
\hline $1961-1970$ & $\begin{array}{r}\mathbf{0 . 0 0 4 8 8 3} \\
(0.000156)\end{array}$ & $\begin{array}{r}\mathbf{0 . 0 0 9 8 2 8} \\
(0.000314)\end{array}$ & $\begin{array}{r}\mathbf{0 . 0 0 1 4 6 4} \\
(0.000089)\end{array}$ & $\begin{array}{r}\mathbf{0 . 0 0 6 3 1 7} \\
(0.000383)\end{array}$ & $\begin{array}{r}-0.014217 \\
(0.016842)\end{array}$ & $\begin{array}{r}-0.022907 \\
(0.032717)\end{array}$ \\
\hline $1971-1980$ & $\begin{array}{r}\mathbf{0 . 0 1 5 0 6 0} \\
(0.000812)\end{array}$ & $\begin{array}{r}\mathbf{0 . 0 1 4 7 4 5} \\
(0.000795)\end{array}$ & $\begin{array}{r}\mathbf{0 . 0 0 3 5 7 2} \\
(0.000316)\end{array}$ & $\begin{array}{r}\mathbf{0 . 0 0 7 4 9 6} \\
(0.000663)\end{array}$ & $\begin{array}{r}-0.194241 \\
(0.130384)\end{array}$ & $\begin{array}{r}-0.065936 \\
(0.092213)\end{array}$ \\
\hline $1981-1990$ & $\begin{array}{r}\mathbf{0 . 0 3 4 2 6 0} \\
(0.003132)\end{array}$ & $\begin{array}{r}\mathbf{0 . 0 3 3 0 0 3} \\
(0.003017)\end{array}$ & $\begin{array}{r}\mathbf{0 . 0 0 7 3 8 3} \\
(0.000675)\end{array}$ & $\begin{array}{r}\mathbf{0 . 0 1 5 2 4 5} \\
(0.001393)\end{array}$ & $\begin{array}{r}-1.800040 \\
(0.956503)\end{array}$ & $\begin{array}{r}-0.337914 \\
(0.518025)\end{array}$ \\
\hline \begin{tabular}{|c|}
$1926-1990$ \\
\end{tabular} & $\begin{array}{r}\mathbf{0 . 0 0 8 1 7 1} \\
(0.000300)\end{array}$ & $\begin{array}{r}\mathbf{0 . 0 1 0 1 3 7} \\
(0.000372)\end{array}$ & $\begin{array}{c}\mathbf{0 . 0 0 2 7 7 4} \\
(0.000346)\end{array}$ & $\begin{array}{r}\mathbf{0 . 0 0 7 3 7 7} \\
(0.000921)\end{array}$ & $\begin{array}{r}-\mathbf{0 . 1 4 3 2 3 1} \\
(0.052563)\end{array}$ & $\begin{array}{r}-0.048425 \\
(0.044541)\end{array}$ \\
\hline
\end{tabular}

Note: Standard Deviations between parentheses; Bold numbers indicate significance at the $95 \%$ confidence level. 
Table 5D

Adjusted Elsticity of Cost with Respect to Output - Bayesian Estimation Average By Decade, Thirtle's Data Set

\begin{tabular}{|c|c|c|c|c|c|c|}
\hline Decade & $\varepsilon_{\mathrm{cy}}$ & $\varepsilon_{\mathrm{cg}}$ & $\varepsilon_{\mathrm{gy}}$ & $\varepsilon_{\mathrm{cr}}$ & $\varepsilon_{\mathrm{ry}}$ & $\varepsilon_{c y}^{A}$ \\
\hline $1926-1930$ & $\begin{array}{r}\mathbf{0 . 2 5 4 1 7 4 4} \\
(0.037726)\end{array}$ & $\begin{array}{r}-0.006194 \\
(0.001260)\end{array}$ & $\begin{array}{r}31.703726 \\
(61.520560)\end{array}$ & $\begin{array}{r}-0.004318 \\
(0.002779)\end{array}$ & $\begin{array}{l}162.18955 \\
(576.973190)\end{array}$ & $\begin{array}{r}-0.642471 \\
(2.014419)\end{array}$ \\
\hline $1931-1940$ & $\begin{array}{l}\mathbf{0 . 2 5 2 0 6 2 9} \\
(0.03225640)\end{array}$ & $\begin{array}{r}-\mathbf{0 . 0 0 8 6 2 8} \\
(0.001607)\end{array}$ & $\begin{array}{r}24.292787 \\
(47.139755)\end{array}$ & $\begin{array}{r}-0.003765 \\
(0.002680)\end{array}$ & $\begin{array}{r}135.91711 \\
483.511600\end{array}$ & $\begin{array}{r}-0.469226 \\
(1.421129)\end{array}$ \\
\hline $1941-1950$ & $\begin{array}{r}\mathbf{0 . 3 0 0 7 4 6 6} \\
(0.049173)\end{array}$ & $\begin{array}{r}-0.006769 \\
(0.002275)\end{array}$ & $\begin{array}{r}14.536020 \\
(28.206909)\end{array}$ & $\begin{array}{r}-\mathbf{0 . 0 1 1 6 5 8} \\
(0.005719)\end{array}$ & $\begin{array}{l}75.291513 \\
(267.842060)\end{array}$ & $\begin{array}{r}-0.675421 \\
(2.765897)\end{array}$ \\
\hline $1951-1960$ & $\begin{array}{r}\mathbf{0 . 3 1 1 5 2 2 1} \\
(0.052183)\end{array}$ & $\begin{array}{r}-0.009544 \\
(0.004696)\end{array}$ & $\begin{array}{r}8.7746229 \\
(17.027012)\end{array}$ & $\begin{array}{r}-0.019486 \\
(0.012929)\end{array}$ & $\begin{array}{r}33.4145 \\
(118.868760)\end{array}$ & $\begin{array}{r}-0.423318 \\
(2.006424)\end{array}$ \\
\hline $1961-1970$ & $\begin{array}{r}\mathbf{0 . 3 9 8 6 1 7 6} \\
(0.066632)\end{array}$ & $\begin{array}{r}-\mathbf{0 . 0 1 1 6 8 5} \\
(0.006470)\end{array}$ & $\begin{array}{r}5.2357006 \\
(10.159791)\end{array}$ & $\begin{array}{r}-\mathbf{0 . 0 2 1 5 0 9} \\
(0.009547)\end{array}$ & $\begin{array}{l}34.515723 \\
(122.786250)\end{array}$ & $\begin{array}{r}-0.404974 \\
(2.240912)\end{array}$ \\
\hline $1971-1980$ & $\begin{array}{r}\mathbf{0 . 6 7 3 8 8 0 8} \\
(0.118328)\end{array}$ & $\begin{array}{r}-0.097684 \\
(0.052232)\end{array}$ & $\begin{array}{r}2.187351 \\
(4.244519)\end{array}$ & $\begin{array}{r}-\mathbf{0 . 0 4 4 1 8 3} \\
(0.023146)\end{array}$ & $\begin{array}{l}29.645173 \\
(105.459750)\end{array}$ & $\begin{array}{r}-0.849587 \\
(5.252431)\end{array}$ \\
\hline $1981-1990$ & $\begin{array}{r}1.2376389 \\
(0.229472)\end{array}$ & $\begin{array}{r}-0.586956 \\
(0.240920)\end{array}$ & $\begin{array}{r}1.1740348 \\
(2.278195)\end{array}$ & $\begin{array}{r}-0.145076 \\
(0.117257)\end{array}$ & $\begin{array}{r}16.173215 \\
(57.534601)\end{array}$ & $\begin{array}{r}-1.797815 \\
(12.154252)\end{array}$ \\
\hline $1926-1990$ & $\begin{array}{r}\mathbf{0 . 4 6 7 8 2 7 7} \\
(0.087865)\end{array}$ & $\begin{array}{r}-0.067493 \\
(0.020796)\end{array}$ & $\begin{array}{r}2.8619869 \\
(5.553639)\end{array}$ & $\begin{array}{r}-\mathbf{0 . 0 3 1 3 5 0} \\
(0.008366)\end{array}$ & $\begin{array}{l}30.614636 \\
(108.908520)\end{array}$ & $\begin{array}{r}-0.685106 \\
(3.549299)\end{array}$ \\
\hline
\end{tabular}

Note: Standard Deviations between parentheses; Bold numbers indicate significance at the $95 \%$ confidence level. 
Table 6. Ball's vs Thirtle's ITSUR - Endogenous Growth Hypotheses

\begin{tabular}{|l|ll|} 
& Ball & Thirtle \\
\hline Positive shadows for public inputs & No, infrastructure & No, infastructure \\
Positive impact on private capital & No, infrastructure & No, research \\
Increasing returns to scale & No & Yes \\
\hline
\end{tabular}

Table 7. Ball's vs Thirtle's Bayesian - Endogenous Growth Hypotheses

\begin{tabular}{|l|ll|}
\hline & Ball & Thirtle \\
\hline Positive shadows for public inputs & Yes & Yes \\
Positive impact on private capital & No, research & Yes \\
Increasing returns to scale & No & Yes (?) \\
\hline
\end{tabular}


Table 8. Ball's vs Thirtle's ITSUR violations

\begin{tabular}{|l|ll|}
\hline \multicolumn{2}{|l|}{ Ball } & Thirtle \\
\hline Monotonicity & No, G, 46/46 obs. & No, R 10/65 obs., G 65/65 obs. \\
Concavity & Yes & No \\
Stability & Yes & No, one igenvalue \\
Euler & No, K, 4/46 obs. & No, K 45/65, L 47/65 obs. \\
Adjustment Cost & No, K, 36/46 obs. & No, K 41/65, L 25/65 obs. \\
Positive Marginal Cost & No, 1/46 obs. & No, 25/65 obs. \\
\hline
\end{tabular}

Table 9. Ball's vs Thirtle's Bayesian violations

All conditions in all data points: parameter space empty

All conditions in $80 \%$ of data points: parameter space empty

Euler equations and adjustment costs conditions dropped

\begin{tabular}{|l|ll|}
\hline \multicolumn{2}{|c|}{ Ball } & Thirtle \\
\hline Monotonicity & No, J, 7/46 obs. & Yes \\
Mon. in public inputs & imposed & imposed \\
Concavity & imposed & imposed \\
Stability & imposed & Yes \\
Euler & No, K 5/46 obs., L 17/46 obs. & Yes \\
Adjustment Cost & No, K 34/46 obs., L 43/46 obs. No, K 20/65 obs., L 55/65 obs. \\
Positive Marginal Cost & imposed & Yes \\
\hline
\end{tabular}


Table 10

Estimated Speed of Adjustment

\begin{tabular}{|c|c|r|r|}
\hline \multicolumn{2}{|c|}{ NLITSUR } & \multicolumn{1}{c|}{ K-K* } & \multicolumn{1}{c|}{ L-L* } \\
\hline Ball's Data Set ('48-'94) & $\Delta \mathrm{K}$ & -0.092 & -0.164 \\
& $\Delta \mathrm{L}$ & 0.049 & -0.195 \\
\hline Thirtle's Data Set ('25-'90) 1967=1 & $\Delta \mathrm{K}$ & 0.095 & -0.008 \\
(It is not stable) & $\Delta \mathrm{L}$ & -0.239 & -0.046 \\
\hline
\end{tabular}

\begin{tabular}{|l|c|r|r|}
\hline \multicolumn{2}{|c|}{ MH Estimation } & \multicolumn{1}{c|}{ K-K* } & \multicolumn{1}{c|}{ L-L* } \\
\hline Ball's Data Set ('48-'94) & $\Delta \mathrm{K}$ & -0.203 & 0.053 \\
& $\Delta \mathrm{L}$ & -0.416 & -0.129 \\
\hline Thirtle's Data Set ('25-'90) 1967=1 & $\Delta \mathrm{K}$ & -0.051 & -0.012 \\
& $\Delta \mathrm{L}$ & -0.019 & -0.069 \\
\hline
\end{tabular}

Estimated Speed of Adjustment - Other Studies

\begin{tabular}{|c|c|c|c|c|}
\hline & \\
\hline & & $\mathrm{K}-\mathrm{K}^{*}$ & L-L* & Land-Land* \\
\hline \multirow{3}{*}{$\begin{array}{l}\text { Vasavada \& Cambers (1986) } \\
\text { 1947-1979 }\end{array}$} & $\Delta \mathrm{K}$ & -0.12 & 0.05 & -0.02 \\
\hline & $\Delta \mathrm{L}$ & 0.22 & -0.07 & -0.34 \\
\hline & $\Delta$ Land & -0.02 & 0.07 & -0.59 \\
\hline \multirow[t]{2}{*}{ Luh and Stefanou (1991) - 1950-1982 } & $\Delta \mathrm{K}$ & -0.13 & 0.01 & -- \\
\hline & $\Delta \mathrm{L}$ & 0.29 & -0.13 & -- \\
\hline \multirow{2}{*}{ Imposing Independent Adjustment } & $\Delta \mathrm{K}$ & -0.15 & 0 & -- \\
\hline & $\Delta \mathrm{L}$ & 0 & -0.11 & -- \\
\hline \multirow[t]{2}{*}{ Luh and Stefanou (1993) - 1950-1982 } & $\Delta \mathrm{K}$ & -0.83 & 0.01 & -- \\
\hline & $\Delta \mathrm{L}$ & 0.84 & -0.11 & -- \\
\hline \multirow{2}{*}{ Imposing Independent Adjustment } & $\Delta \mathrm{K}$ & -0.99 & 0 & -- \\
\hline & $\Delta \mathrm{L}$ & 0 & -0.11 & -- \\
\hline \multirow{2}{*}{$\begin{array}{l}\text { Luh and Stefanou (1996) - 1948-1982 } \\
\text { CVW }\end{array}$} & $\Delta \mathrm{K}$ & -0.34 & -0.24 & -- \\
\hline & $\Delta \mathrm{L}$ & -0.36 & -0.45 & -- \\
\hline \multirow{2}{*}{$\begin{array}{l}\text { Luh and Stefanou (1996) - 1948-1987 } \\
\text { USDA }\end{array}$} & $\Delta \mathrm{K}$ & -0.33 & 0.02 & -- \\
\hline & $\Delta \mathrm{L}$ & -0.03 & -0.27 & -- \\
\hline \multirow{2}{*}{ Imposing Independent Adjustment } & $\Delta \mathrm{K}$ & -0.35 & 0 & -- \\
\hline & $\Delta \mathrm{L}$ & 0 & -0.26 & -- \\
\hline \multirow{2}{*}{ Imposing Independent Adjustment and static expectations } & $\Delta \mathrm{K}$ & -0.44 & 0 & -- \\
\hline & $\Delta \mathrm{L}$ & 0 & -0.33 & -- \\
\hline
\end{tabular}




\section{REFERENCES}

Alston, J. and P. Pardey, Making Science Pay, AEI Press, 1996.

Allen, C. and G. Urga."Interrelated Factor Demand from Dynamic Cost Functions: An Application to the Non-energy Business Sector of the UK Economy." Economica 66 (1996): 403-13.

Antle, J. "Infrastructure and Aggregate Agricultural Productivity: International Evidence." Economic Development and Cultural Change 31 v3 (1983): 609-19.

Aschauer, D. A. "Is Public Expenditure Productive?." Journal of Monetary Economics 23 (March 1989): 177-200.

Atkinson, S. and J. Dorfman (2001). "Crediting Electric Utilities for Reducing Air Pollution Bayesian Measurement of Productivity and Efficiency," Working Paper, University of Georgia.

Ball, E., J. Bureau, R. Nehring, and A. Sonwaru. "Agricultural Productivity Revisited," Amer. J. Agr. Econ. 79 (November 1997): 1045-63.

Barro, R., "Government Spending in a Simple model of Endogenous Growth." Journal of Political Economy, 98 (October1990), Part II: S103-S125.

Barro, R., and X. Sala-I-Martin. Economic Growth, McGraw-Hill, 1995.

Barten, A. "Maximum Likelihood Estimation of a Complete System of Demand Equations" European Economic Review, 1 (1969): 7-73.

Berndt, E. and B. Hansson. "Measuring the Contribution of Public Infrastructure Capital in Sweden." Scandinavian Journal of Economics 94 (Supplement 1992): s151-72.

Binswanger, H., S. Khandker and M. Rosenzweig, "How infrastructure and financial institutions affect agricultural output and investment in India." Journal of Development Economics 41 (1993): 337-66

Cassella, G. and E. George (1992). "Explaining the Gibbs Sampler," Journal of American Statistical Association, Vol. 46, No. 3 (August): 167-174.

Chalfant, J. and K. White. "Estimation and Testing in Demand Systems with Concavity Constraints." Working Paper. Department of Agricultural and Resource Economics, University of California at Berkeley, 1987. 
Chalfant, J., R. Gray and K. White. "Evaluating Prior Beliefs in a Demand System: The Case of Meats Demand in Canada." Working Paper. Department of Agricultural and Resource Economics, University of California at Berkeley, 1989.

Chambers, R. Applied Production Analysis - The Dual Approach. Cambridge University Press 1988.

Chib, S. and E. Greenberg (1996). "Markov Chain Monte Carlo Simulation Methods in Econometrics," Econometric Theory, Vol. 12: 409-431.

Craig, B., P. Pardey, and J. Roseboom. "International Productivity Patterns: Accounting for Input Quality, Infrastructure, and Research." Amer. J. Agr. Econ. 79 (November 1997): 1064-76.

Diewert, E. and T. Wales (1987). "Flexible Functional Forms and Global Curvature Conditions," Econometrica, 55 (January): 43-68.

Epstein, L. "The Multivariate Flexible Accelerator Model: Its Empirical Restrictions and an Application to U.S. Manufacturing.” Econometrica, Vol. 51, No 3 (May, 1983): 647674.

Epstein, L. "Duality Theory and Functional Forms for Dynamic Factor Demands." Review of Economic Studies, 48 (1981): 81-95.

Garcia-Mila, T. and McGuire, T. "The Contribution of Publicly Provided Inputs to States' Economies." Regional Science and Urban Economics 22 (June 1992): 229-42.

Geweke, J. "Exact Inference in the Inequality Constrained Normal Linear Regression Model." Journal of Applied Econometrics, 1 (1986): 127-141.

Geweke, J. (1992). "Evaluating the Accuracy of Sampling-Based Approaches to Calculating Posterior Moments," Bayesian Statistics 4, edited by J. Bernardo, J. Berger, A. David, and A. Smith, Oxford, Clarendon Press, UK.

Griffiths, W., C. O’Donnell, and A. Tan Cruz (1999). "Imposing Regularity Conditions on a System of Cost and Factor Share Equations," Working Paper Series in Agricultural Economics, University of New England.

Fousekis P. and S. Stefanou. "Capacity Utilization Under Dynamic Profit Maximization." Empirical Economics 21 (1996):335-59.

Holtz-Eakin, D. "Public Sector Capital and the Productivity Puzzle." Review of Economics and Statistics 76 (February 1994): 12-21. 
Howard, W. and R. Shumway. "Dynamic Adjustment in the U.S. Diary Industry." Amer. J. Agr. Econ. 70 (November 1988): 837-47.

Huffman, W. and R. Evenson, "Supply and Demand Functions for Multiproduct US Cash Grain Farms: Biases Caused by Research and Other Policies." Amer. J. Agr. Econ. 71 (August 1989): 761-73.

Huffman, W., V. E. Ball, M. Gopinath, and A. Somwaru, "Public R\&D and Infrastructure Policies: Effects on Cost of Midwestern Agriculture." Chapter 7 in Ball, V. E. and G. W. Norton Agricultural Productivity: Measurement and Sources of Growth, KAP, 2002

Judge, G., H. Luetkepohl, R. Carter Hill, T. Lee, and W. Griffiths (1985). The Theory and Practice of Econometrics, Wiley, New York.

Judge, G, H. Lukepohl, R. Carter Hill, T. Lee, and W. Griffiths (1988). Introduction to the theory and practice of econometrics, Wiley, New York.

Luh Y. and S. Stefanou. "Productivity Growth in U.S. Agriculture under Dynamic Adjustment." American Journal of Agricultural Economics 73 (Nov. 1991), 11161125 .

Luh Y. and S. Stefanou. "Learning-by-Doing and the Sources of Productivity Growth: A Dynamic Model with Applications to U.S. Agriculture." Journal of Productivity Analysis 4 (1993): 353-370.

Luh Y. and S. Stefanou. "Asymmetric Adjustment of Dynamic Factors at the Firm Level." American Journal of Agricultural Economics 79 (Nov. 1997): 1340-1351.

Luh Y. and S. Stefanou. "Estimating Dynamic Dual Models under Nonstatic Expectations." American Journal of Agricultural Economics 78 (November 1996): 991-1003.

Lynde, C. and J. Richmond. "The Role of Public Capital in Production." Review of Economics and Statistics 74 (February 1992): 37-44.

Morrison, C. and E. Schwartz. "State Infrastructure and Productive Performance." American Economic Review 86 (December 96): 1095-1111.

Munnell, A. "How Does Public Infrastructure Affect Regional Economic Performance?." New England Economic Review (Sept./October 1990): 11-32. 
Nadiri, I. and T. Mamuneas. "The Effects of public Infrastructure and R\&D Capital on the Cost Structure and Performance of U.S. Manufacturing Industries." Review of Economics and Statistics 76 (February 1994): 22-37.

O'Donnell, C., R. Shumway, and E. Ball. "Input Demands and Inefficiency in U.S. Agriculture," American Journal of Agricultural Economics, Vol. 81 (November 1999): 865-880.

O'Donnell, C. J. "Parametric Estimation of Technical and Allocative Efficiency in U.S. Agriculture." Chapter 6 in Ball, V. E. and G. W. Norton Agricultural Productivity: Measurement and Sources of Growth, KAP, 2002.

Oude Lansink, A. and S. Stefanou. "Asymmetric Adjustment of Dynamic Factors at the Firm Level." American Journal of Agricultural Economics 79 (November 1997): 1340-51.

Romer, P. "Increasing Returns and Long-Run Growth.” Journal of Political Economy 94 (October 1986): 1002-37.

Romer, P. "Endogenous Technological Change." Journal of Political Economy 98 Part II (October 1990): S71-S102.

Stefanou, S. "Returns to Scale in the Long Run: The Dynamic Theory of Cost." Southern Economic Journal 55 (January 1989): 570-79.

Taylor, T. and M. Monson. "Dynamic Factor Demands for Aggregate Southeastern United States Agriculture." Southern Journal of Agricultural Economics 17 (December 1985): $1-9$.

Thirtle, C., D. Schimmelpfenning, and R. Townsend. "Induced Innovation in United States Agriculture, 1880-1990: Time Series Tests and an Error Correction Model." American Journal of Agricultural Economics 84 (August 2002): 598-614.

Urga, G. and C. Walters. "Dynamic Translog and linear logit models: a factor demand analysis of interfuel substitution in US industrial energy demand." Energy Economics 25 (2003): 1-21.

Vasavada, U. and E. Ball. "A Dynamic Adjustment Model of U.S. Agriculture: 1948-1979." Agricultural Economics 2 (1988): 123-137.

Vasavada, U. and R. Chambers. "Investment in U.S. Agriculture." Amer. J. Agr. Econ. 68 (November 1986): 950-60. 


\section{APPENDIX 1} of the firms.

This appendix presents conditions (A) and (B) that guarantee duality between cost and value functions

\section{Conditions (A)}

It is assumed that $\mathrm{C}(\mathrm{y}, \mathrm{Z}, \mathrm{I} ; \mathrm{G})$ satisfies the following set of regularity conditions:

(A.1) $\quad \mathrm{C}(\mathrm{y}, \mathrm{Z}, \mathrm{I} ; \mathrm{G}) \geq 0$.

(A.2) $\mathrm{C}(\mathrm{y}, \mathrm{Z}, \mathrm{I} ; \mathrm{G})$ is increasing in $\mathrm{y}$ and decreasing in $\mathrm{Z}$. Additionally, $\mathrm{C}_{\mathrm{I}}>0$ when $\mathrm{I}>0$ and vice versa, which follows from the assumption of adjustment costs.

(A.3) $\quad \mathrm{C}(\mathrm{y}, \mathrm{Z}, \mathrm{I} ; \mathrm{G})$ is convex in I.

(A.4) For each $\left(Z_{0}, y, p ; G\right)$ a unique solution exists for (1). This means that there are well-defined factor demand functions associated with (1).

(A.5) For each $\left(Z_{0}, y, p ; G\right)$, problem (1) has a unique steady state (SS) stock $\bar{Z}(y, p ; G)$ that is globally stable. This condition establishes the uniqueness and stability of the steady state.

(A.6) For any $\left(Z_{0}, y, p ; G\right)$, there exists $p$ such that $I$ is the optimal gross investment vector at $t=0$ in (1) given $\left(Z_{0}, y, p ; G\right)$.

\section{Conditions (B)}

It is assumed that the value function $\mathrm{J}(\mathrm{Z}, \mathrm{y}, \mathrm{p} ; \mathrm{G})$ satisfies the following properties:

(B.1) $\quad \mathrm{J}(\mathrm{Z}, \mathrm{y}, \mathrm{p} ; \mathrm{G}) \geq 0$.

(B.2) (i) $(r u+\delta) J_{z}(Z, y, p ; G)-p-J_{z z}(Z, y, p ; G) \dot{Z}^{*}(Z, y, p ; G)<0$, where u is an identity matrix. This expression is dual to $\mathrm{C}_{z}<0$.

(ii) $\mathrm{J}_{\mathrm{Z}}(\mathrm{Z}, \mathrm{y}, \mathrm{p} ; \mathrm{G})<0$ when $\mathrm{I}^{*}(\mathrm{Z}, \mathrm{y}, \mathrm{p} ; \mathrm{G}) \equiv \mathbf{Z}^{*}(\mathrm{Z}, \mathrm{y}, \mathrm{p} ; \mathrm{G})+\delta \mathrm{Z}>0$ and vice versa. This condition is dual to $C_{I}>0$ when $I>0$ and vice versa.

(iii) $\rho J_{y}(Z, y, p ; G)-J_{y z}^{\prime}(Z, y, p ; G) \dot{Z}^{*}(Z, y, p ; G)>0$, where

$$
\dot{Z}^{*}(Z, y, p ; G)=J_{p z}^{-1}(Z, y, p ; G)[\rho J p(Z, y, p ; G)-Z] \text {. This condition is dual to } C_{y}>0 \text {. }
$$

(B.3) The following expression is concave in $\mathrm{p}$ :

$$
\rho J(Z, y, p ; G)-p^{\prime} Z-J_{Z}^{\prime}(Z, y, p ; G) \dot{Z}^{*}(Z, y, p ; G)
$$

Under some specific functional forms (like the normalized quadratic presented above), $J_{z}(Z, y, p ; G)$ is linear in $\mathrm{p}$ and the curvature requirement reduces to concavity of $\mathrm{J}(\mathrm{Z}, \mathrm{y}, \mathrm{p} ; \mathrm{G})$ in $\mathrm{p}$. This condition is dual to (A.3)

(B.4) The demand for the variable input, $X^{*}(Z, y, p ; G)$, is positive.

(B.5) The stock $Z$ that solves $\dot{Z}^{*}(Z, y, p ; G)=J_{p Z}^{-1}(Z, y, p ; G)[\rho J p(Z, y, p ; G)-Z]$, with $Z(0)>0$, has a unique globally stable steady state $\bar{Z}(y, p ; G)$.

Then, under conditions (A) and (B), duality between $\mathrm{C}(\mathrm{y}, \mathrm{Z}, \mathrm{I} ; \mathrm{G}$.) and $\mathrm{J}(\mathrm{Z}, \mathrm{y}, \mathrm{p} ; \mathrm{G})$ can be established as in equations (2) and (3). The following derivative properties then hold:

\section{Derivative Properties}

1. With respect to I:

$\mathrm{C}_{\mathrm{I}}(\mathrm{y}, \mathrm{Z}, \mathrm{I} ; \mathrm{G})=-\mathrm{J}_{\mathrm{Z}}(\mathrm{Z}, \mathrm{y}, \mathrm{p} ; \mathrm{G})$. From (A.2) or (B.2.ii), this expression must be positive when I $>0$ and vice versa.

Testing for $J_{z}(Z, y, p ; G)=0$ is equivalent to testing for adjustment costs in inputs $Z$. 
2. With respect to $Z$ :

$\mathrm{C}_{\mathrm{z}}(\mathrm{y}, \mathrm{Z}, \mathrm{I} ; \mathrm{G})=(\rho \mathrm{u}+\delta) \mathrm{J}_{\mathrm{z}}(\mathrm{Z}, \mathrm{y}, \mathrm{p} ; \mathrm{G})-\mathrm{p}-\mathrm{J}_{\mathrm{zz}}(\mathrm{Z}, \mathrm{y}, \mathrm{p} ; \mathrm{G}) \dot{Z}^{*}(\mathrm{Z}, \mathrm{y}, \mathrm{p} ; \mathrm{G})<0$ from (A.2).

This expression gives the shadow price of quasi-fixed inputs.

3. With respect to $y$ :

$\mathrm{C}_{\mathrm{y}}(\mathrm{y}, \mathrm{Z}, \mathrm{I} ; \mathrm{G})=\rho \mathrm{J}_{\mathrm{y}}(\mathrm{Z}, \mathrm{y}, \mathrm{p} ; \mathrm{G})-\mathrm{J}_{\mathrm{zy}}^{\prime}(\mathrm{Z}, \mathrm{y}, \mathrm{p} ; \mathrm{G}) \dot{Z}^{*}(Z, y, p ; G)>0$ from (A.2).

This expression represents the output supply of the firms.

4. With respect to $p$ :

$0=\rho J_{p}(Z, y, p ; G)-Z-J_{z p}(Z, y, p ; G) \dot{Z}^{*}(Z, y, p ; G)$

Then,

$\dot{Z}^{*}(Z, y, p ; G)=J_{p z}^{-1}(Z, y, p ; G)\left[\rho J_{p}(Z, y, p ; G)-Z\right]$, which is the dynamic demand for $Z$.

5. With respect to G:

$\mathrm{C}_{\mathrm{G}}(\mathrm{y}, \mathrm{Z}, \mathrm{I} ; \mathrm{G})=\rho \mathrm{J}_{\mathrm{G}}(\mathrm{Z}, \mathrm{y}, \mathrm{p} ; \mathrm{G})-\mathrm{J}_{\mathrm{ZG}}(\mathrm{Z}, \mathrm{y}, \mathrm{p} ; \mathrm{G}) \dot{\mathrm{Z}}^{*}(\mathrm{Z}, \mathrm{y}, \mathrm{p} ; \mathrm{G})$

This expression represents the shadow price of $G$ when the firms are out of the SS. At the SS, the shadow price is

$\mathrm{C}_{\mathrm{G}}(\mathrm{y}, \mathrm{Z}, \mathrm{I} ; \mathrm{G})=\rho \mathrm{J}_{\mathrm{G}}(\mathrm{Z}, \mathrm{y}, \mathrm{p} ; \mathrm{G})$

If this expression is negative, the shadow price of $\mathrm{G}$ is positive, meaning that public inputs reduce cost of production.

\section{APPENDIX 2}

This appendix presents conditions (C) to (D) that guarantee duality between the value function of the firms and the value function of the government.

\section{Conditions $(C)$}

It is assumed that $\mathrm{J}(\mathrm{y}, Z, \mathrm{p} ; \mathrm{G})+\mathrm{AC}\left(\mathrm{I}_{\mathrm{g}}\right)$ satisfies the following conditions:

(C.1) $\quad \mathrm{J}(\mathrm{y}, \mathrm{Z}, \mathrm{p} ; \mathrm{G})+\mathrm{AC}\left(\mathrm{I}_{\mathrm{g}}\right) \geq 0$

(C.2) (i) $\mathrm{J}(\mathrm{y}, \mathrm{Z}, \mathrm{p} ; \mathrm{G})+\mathrm{AC}\left(\mathrm{I}_{\mathrm{g}}\right)$ is increasing in $\mathrm{I}_{\mathrm{g}}$. Given that $\mathrm{J}(\mathrm{y}, \mathrm{Z}, \mathrm{p} ; \mathrm{G})$ is independent of $\mathrm{I}_{\mathrm{g}}, \mathrm{AC}\left(\mathrm{I}_{\mathrm{g}}\right)$ must be increasing in $I_{g}$.

(ii) $\mathrm{J}(\mathrm{y}, \mathrm{Z}, \mathrm{p} ; \mathrm{G})+\mathrm{AC}\left(\mathrm{I}_{\mathrm{g}}\right)$ is decreasing in $\mathrm{G}$. Given that $\mathrm{AC}\left(\mathrm{I}_{\mathrm{g}}\right)$ is independent of $\mathrm{G}, \mathrm{J}(\mathrm{y}, \mathrm{Z}, \mathrm{p} ; \mathrm{G})$ must be decreasing in $\mathrm{G}$.

(C.3) $\mathrm{J}(\mathrm{y}, \mathrm{Z}, \mathrm{p} ; \mathrm{G})+\mathrm{AC}\left(\mathrm{I}_{\mathrm{g}}\right)$ is convex in $\mathrm{I}_{\mathrm{g}}$. Then, $\mathrm{AC}\left(\mathrm{I}_{\mathrm{g}}\right)$ must be convex in $\mathrm{I}_{\mathrm{g}}$.

(C.4) For each $\left(Z, p, y, r, G_{0}\right)$, there exists a unique solution for (8). This means that there are well-defined supplies of public inputs.

(C.5) For each $\left(\mathrm{Z}, \mathrm{p}, \mathrm{y}, \mathrm{r}, \mathrm{G}_{0}\right),(8)$ has a unique steady state stock $\overline{\mathrm{G}}(\mathrm{Z}, \mathrm{p}, \mathrm{y}, \mathrm{r})$ that is globally stable.

(C.6) For any ( $\left.Z, p, y, r, G_{0}\right)$, there exists $r$ such that $I_{g}$ is the optimal public gross investment vector at $t=0$ in $(8)$, given $\left(Z, p, y, r, G_{0}\right)$.

\section{Conditions (D)}

It is assumed that $\mathrm{J}^{\mathrm{g}}(\mathrm{y}, \mathrm{Z}, \mathrm{p} ; \mathrm{r}, \mathrm{G})$ satisfies the following conditions:

(D.1) $\quad \mathrm{J}^{\mathrm{g}}(\mathrm{y}, \mathrm{Z}, \mathrm{p} ; \mathrm{r}, \mathrm{G}) \geq 0$

(D.2) (i) $\mathrm{J}_{\mathrm{G}}^{\mathrm{g}}(\mathrm{y}, \mathrm{Z}, \mathrm{p} ; \mathrm{r}, \mathrm{G})<0$. This condition is dual to (C.2)(i) and means that there are adjustment costs in the provision of public inputs. 
(ii) $\left(\theta u+\delta_{g}\right) J_{G}^{g}(y, Z, p ; r, G)-J_{G G}^{g}(y, Z, p ; r, G) \dot{G}^{*}<0$. This expression is dual to (C.2)(ii): $\mathrm{J}_{\mathrm{G}}(\mathrm{y}, \mathrm{Z}, \mathrm{p} ; \mathrm{r}, \mathrm{G})<0$ (positive shadow prices of public inputs). Given $\mathrm{J}_{\mathrm{G}}^{\mathrm{g}}(\mathrm{y}, \mathrm{Z}, \mathrm{p} ; \mathrm{r}, \mathrm{G})<0$, it is sufficient for (D.2)(ii) to hold that $-\mathrm{J}_{\mathrm{GG}}^{\mathrm{g}}(\mathrm{y}, \mathrm{Z}, \mathrm{p} ; \mathrm{r}, \mathrm{G})<0$ (that is, increases of the public good decrease the shadow price of it).

(D.3) $\quad \theta \mathbf{J}^{\mathrm{g}}(\mathrm{Z}, \mathrm{y}, \mathrm{p}, \mathrm{r}, \mathrm{G})-\mathrm{r}^{\prime} \mathrm{G}-\mathrm{J}_{\mathrm{G}}^{\mathrm{g}}{ }^{\prime}(\mathrm{Z}, \mathrm{y}, \mathrm{p}, \mathrm{r}, \mathrm{G}) \dot{\mathrm{G}}^{*}$ must be concave in $\mathrm{r}$. This is dual to condition (C.3).

(D.4) $\quad \mathrm{I}_{\mathrm{g}}^{*}(\mathrm{y}, \mathrm{Z}, \mathrm{p} ; \mathrm{r}, \mathrm{G}) \equiv \dot{\mathrm{G}}^{*}(\mathrm{y}, \mathrm{Z}, \mathrm{p} ; \mathrm{r}, \mathrm{G})+\delta_{\mathrm{g}} \mathrm{G}$ is positive.

(D.5) The stocks $G$ that solve $\dot{G}^{*}(y, Z, p ; r, G)=J_{G r}^{g-1}(y, Z, p ; r, G)\left[\theta J_{r}^{g}(y, Z, p ; r, G)-G\right]$,

with $\mathrm{G}(0)>0$, has a unique globally stable steady state $\overline{\mathrm{G}}(\mathrm{Z}, \mathrm{p}, \mathrm{y} ; \mathrm{r})$.

Then, under conditions (C) and (D), duality between $\mathrm{J}^{\mathrm{g}}(\mathrm{y}, \mathrm{Z}, \mathrm{p} ; \mathrm{r}, \mathrm{G})$ and $\mathrm{J}(\mathrm{y}, \mathrm{Z}, \mathrm{p} ; \mathrm{r}, \mathrm{G})+\mathrm{AC}\left(\mathrm{I}_{\mathrm{g})}\right.$ can be established as in equations (9) and (10). The derivative properties presented below then hold.

Derivative Properties

1. With respect to $\mathrm{I}_{\mathrm{g}}$ :

$0=\mathrm{AC}_{\mathrm{I}_{\mathrm{g}}}+\mathrm{J}_{\mathrm{G}}^{\mathrm{g}}(\mathrm{p}, \mathrm{Z}, \mathrm{y} ; \mathrm{r}, \mathrm{G})$

or

$-\mathrm{J}_{\mathrm{G}}^{\mathrm{g}}(\mathrm{p}, \mathrm{Z}, \mathrm{y} ; \mathrm{r}, \mathrm{G})=\mathrm{AC}_{\mathrm{I}_{\mathrm{g}}}>0$,

This is positive given $\mathrm{AC}_{\mathrm{Ig}}>0$.

2. With respect to $\mathrm{G}$ :

$\theta \mathbf{J}_{G}^{\mathrm{g}}(\mathrm{p}, \mathrm{Z}, \mathrm{y} ; \mathrm{r}, \mathrm{G})=\mathbf{J}_{\mathrm{G}}(\mathrm{Z}, \mathrm{y}, \mathrm{p} ; \mathrm{G})+\mathrm{r}+\mathrm{J}_{\mathrm{GG}}^{\mathrm{g}}(\mathrm{p}, \mathrm{Z}, \mathrm{y} ; \mathrm{r}, \mathrm{G}) \dot{\mathrm{G}}^{*}-\delta_{\mathrm{g}} \mathrm{J}_{\mathrm{G}}^{\mathrm{g}}(\mathrm{p}, \mathrm{Z}, \mathrm{y} ; \mathrm{r}, \mathrm{G})$

or

$J_{G}(Z, y, p ; G)=\left(\theta u+\delta_{g}\right) J_{G}^{g}(p, Z, y ; r, G)-r-J_{G G}^{g}(p, Z, y ; r, G) \dot{G}^{*}$

This expression is the firms' willingness to pay for $G$ (shadow price) when the firms are at the steady state. If the expression is negative (condition (D.2)(ii)), then public inputs reduce cost of production. When the government is also at the $\mathrm{SS}$, that expression can be rewritten as

$-\mathbf{J}_{\mathrm{G}}^{\mathrm{g}}(\mathrm{p}, \mathrm{Z}, \mathrm{y} ; \mathrm{r}, \mathrm{G})=\left(\theta \mathrm{u}+\delta_{\mathrm{g}}\right)^{-1}\left(-\mathrm{J}_{\mathrm{G}}(\mathrm{Z}, \mathrm{y}, \mathrm{p} ; \mathrm{G})-\mathrm{r}\right)$

which could be interpreted as a 'social' shadow price: the net social benefit (the firms' shadow price of $G$ minus the government's cost of providing $\mathrm{G}$ ) adjusted by the 'social' discount rate plus the depreciation rate of public inputs.

3. With respect to $\mathrm{r}$ :

$$
\begin{aligned}
& { }_{\theta}^{J_{r}^{g}}(p, Z, y ; r, G)=G+J_{G r}^{g}(p, Z, y ; r, G) \dot{G}^{*} \\
& \text { or } \\
& \dot{G}^{*}=J_{G r}^{g-1}(p, Z, y ; r, G)\left[\theta J_{r}^{g}(p, Z, y ; r, G)-G\right]
\end{aligned}
$$

which gives the optimal path of $\mathrm{G}$.

4. With respect to $Z$ :

$$
{ }_{\theta} J_{z}^{g}(p, Z, y ; r, G)=J_{z}(Z, y, p ; G)+J_{G z}^{g}(p, Z, y ; r, G) \dot{G}^{*}
$$

or 
$\mathrm{J}_{\mathrm{z}}(\mathrm{Z}, \mathrm{y}, \mathrm{p} ; \mathrm{G})={ }_{\theta} \mathrm{J}_{\mathrm{z}}^{\mathrm{g}}(\mathrm{p}, \mathrm{Z}, \mathrm{y} ; \mathrm{r}, \mathrm{G})-\mathrm{J}_{\mathrm{Gz}}^{\mathrm{g}}(\mathrm{p}, \mathrm{Z}, \mathrm{y} ; \mathrm{r}, \mathrm{G}) \dot{\mathrm{G}}^{*}<0$

where the sign is given by condition B.2(ii): the value function of the firm is decreasing in $Z$.

5. With respect to $\mathrm{y}$ :

${ }_{\theta} \mathbf{J}_{\mathrm{y}}^{\mathrm{g}}(\mathrm{p}, \mathrm{Z}, \mathrm{y} ; \mathrm{r}, \mathrm{G})=\mathbf{J}_{\mathrm{y}}(Z, \mathrm{y}, \mathrm{p} ; \mathrm{G})+\mathbf{J}_{\mathrm{Gy}}^{\mathrm{g}} \mathrm{y}^{\prime}(\mathrm{p}, \mathrm{Z}, \mathrm{y} ; \mathrm{r}, \mathrm{G}) \dot{\mathrm{G}}^{*}$

or

$\mathrm{J}_{\mathrm{y}}(\mathrm{Z}, \mathrm{y}, \mathrm{p} ; \mathrm{G})={ }_{\theta} \mathrm{J}_{\mathrm{y}}^{\mathrm{g}}(\mathrm{p}, \mathrm{Z}, \mathrm{y} ; \mathrm{r}, \mathrm{G})-\mathrm{J}_{\mathrm{Gy}}^{\mathrm{g}} \mathrm{\prime}(\mathrm{p}, \mathrm{Z}, \mathrm{y} ; \mathrm{r}, \mathrm{G}) \dot{\mathrm{G}}^{*}>0$

where the sign is given by condition B.2(iii): the value function of the firm is increasing in $y$. Finally, at the SS level of $G$ (or with no adjustment cost of $G$ ),

$\mathrm{J}_{\mathrm{y}}(\mathrm{Z}, \mathrm{y}, \mathrm{p} ; \mathrm{G})={ }_{{ }_{\mathrm{J}}} \mathrm{J}_{\mathrm{y}}^{\mathrm{g}}(\mathrm{p}, \mathrm{Z}, \mathrm{y} ; \mathrm{r}, \mathrm{G})>0$

The appendices below can be requested from the author or found for the next 15 days at:

$\underline{\text { ftp.ianr.unl.edu }}$

APPENDIX 3. Bayesian Estimation.

APPENDIX 4.Data set (see below)

APPENDIX 5. Additional Diagnostics and Potential Extensions of this Analysis.

APPENDIX 6. Unit root tests

APPENDIX 7. SAS code used in estimation.

APPENDIX 8. Reviewers' comments as of February 21, 2006 (Prof. Alvarez, Prof. Buccola, Prof. Førsund,

Prof. Thirtle, Prof. Karagiannis, Prof. Tsionas) 
APPENDIX 4. Data Sets

\begin{tabular}{|c|c|c|c|c|c|c|c|c|c|}
\hline \multicolumn{10}{|c|}{$\begin{array}{l}\text { BALL's } \\
\text { Period: 1948-1994 } \\
\text { Quantity Indexes: 1987=1 } \\
\text { Implicit Price Indexes }\end{array}$} \\
\hline \multirow[b]{2}{*}{ year } & \multirow{2}{*}{$\begin{array}{c}\text { Output } \\
\mathbf{Q y}\end{array}$} & \multicolumn{2}{|c|}{ Materials } & \multicolumn{2}{|c|}{ Labor } & \multicolumn{2}{|c|}{ Capital+Land } & \multirow{2}{*}{$\begin{array}{c}\text { Infrast.Stock } \\
\text { G }\end{array}$} & $\begin{array}{l}\text { R\&D Stock (exp. } \\
\text { from } \\
\text { Alston+Pardey) }\end{array}$ \\
\hline & & Pm & Qm & PL & $\mathbf{Q L}$ & Qkland & Pkland & & $\mathbf{R}$ \\
\hline Mean & 0.778 & 47874 & 0.893 & 17462 & 1.759 & 1.013 & 32027 & 1167226 & 971 \\
\hline StDev & 0.195 & 25745 & 0.152 & 14261 & 0.700 & 0.099 & 28577 & 1088268 & 1078 \\
\hline Max & 1.198 & 91902 & 1.165 & 51974 & 3.304 & 1.182 & 95942 & 3568275 & 3744 \\
\hline Min & 0.502 & 22413 & 0.574 & 3797 & 0.937 & 0.688 & 3819 & 126061 & 103 \\
\hline
\end{tabular}

\begin{tabular}{|c|c|c|c|c|c|c|c|c|c|}
\hline \multicolumn{10}{|c|}{\begin{tabular}{|l} 
THIRTLE'S \\
Period: $1925-1990$ \\
Quantity Indexes: $1967=1$ \\
Implicit Price Indexes \\
\end{tabular}} \\
\hline \multirow[b]{2}{*}{ Year } & \multirow{2}{*}{$\begin{array}{c}\text { Output } \\
\mathbf{Q y}\end{array}$} & \multicolumn{2}{|c|}{ Fertilizers } & \multicolumn{2}{|c|}{ Labor } & \multicolumn{2}{|c|}{ Capital+Land } & Infrast.Stock & R\&D Stock \\
\hline & & Pm & Qm & PL & $\mathbf{Q L}$ & Qk & $\mathbf{P k}$ & $\mathbf{G}$ & $\mathbf{R}$ \\
\hline Mean & 0.883 & 26656 & 0.734 & 19333 & 1.805 & 0.908 & 18226 & 651309 & 467.0 \\
\hline StDev & 0.287 & 10779 & 0.656 & 19714 & 1.027 & 0.183 & 18204 & 850450 & 432.3 \\
\hline Max & 1.420 & 52670 & 1.961 & 69571 & 3.400 & 1.218 & 58241 & 2966789 & 1574.3 \\
\hline Min & 0.430 & 14428 & 0.050 & 1827 & 0.524 & 0.605 & 3627 & 32194 & 42.0 \\
\hline
\end{tabular}

